\title{
Çevre Hakkının Dayanışma Hakkı Olarak Gelişimi ve Türkiye Özelinde Analizi ${ }^{1}$
}

\author{
İmam Bakır KANLI² - İsmail Tarık KÜPELi³
}

\section{Öz}

Kamu yönetimi disiplini bağlamında özellikle çevre politikalarının üretilmesi, uygulanması ve yönetilmesi süreçlerinde, kamu yararı ve kişisel çıkarlar arasındaki mücadele tarih boyunca hep olmuştur. Bu mücadelenin bir yansıması olarak fiziksel çevrenin tahrip edilmesi sadece doğa ya da insanoğlunu olumsuz yönde etkilememiş, aynı zamanda yapılı çevre de bu yıkımdan payını almıştır. Özellikle son elli yıl boyunca, Birleşmiş Milletler öncülüğ̈̈nde yürütülen çalışmalar göstermiştir ki, çevre sorunlarının çözümünde veya en aza indirgenmesinde, soruna taraf olan paydaşların olabildiğince bir dayanışma ve iş birliği şuuru içinde hareket etmeleri anahtar rol oynamaktadır. Bu yüzdendir ki, bu dayanışmanın çevre hakkı kapsamı içinde "Üçüncü Kuşak Haklar" arasındaki yerini alması, 1982 yılında "Dayanışma Haklarına İlişkin Uluslararası Üçüncü Pakt Ön Tasarısı" ile gerçekleştirilmiştir. İşte bu çalışma, çevre hakkının dayanışma hakkı olarak dünyadaki gelişimini, Türkiye özelindeki yansımalarını ve geçirdiği süreci analiz etmektedir. Makalenin, literatüre yapacağı katkının yanı sıra merkezi ve yerel yönetimlerin ulusal ve uluslararası ölçekte yapacă̆ı çalışmalara veya üretecekleri çevre politikalarına sağlayacağı katkı açısından da önemli olduğu düşünülmektedir. Çalışma, Birleşmiş Milletler, Fransa ve Türkiye’nin 1970 sonrası çevre hakkı konusundaki politikalarıla sınırlandırılmıştır. Nitel araştırma yöntemine dayalı olarak gerçekleştirilen bu çalışmada; literatür taraması yapılmış, literatür ile birlikte ulusal ve uluslararası kurum ve kuruluşların rapor ve analizlerinden veriler elde edilmiştir. Elde edilen veriler ise doküman analizi tekniği ile değerlendirilmiş ve ulaşılan bulguların değerlendirilmesini müteakip yapılan önerilerle de çalışma sonlandırılmıştır.

Anahtar Kelimeler: Birleşmiş Milletler, Çevre, Çevre Hakkı, Çevre Sorunları, Dayanışma Hakları

Atıf: Kanlı, İ. B. ve Küpeli, İ. T. (2021). Çevre hakkının dayanışma hakkı olarak gelişimi ve Türkiye özelinde analizi. Anadolu Üniversitesi Sosyal Bilimler Dergisi, 21(2), 417-448.

\footnotetext{
${ }^{1}$ Bu çalışma etik kurul izin belgesi gerektirmemektedir.

2 Marmara Üniversitesi Siyasal Bilgiler Fakültesi Siyaset Bilimi ve Kamu Yönetimi Bölümü, bkanli@yahoo.com, ORCID: 0000-0002-5715-8752

${ }^{3}$ Marmara Üniversitesi Sosyal Bilimler Enstitüsü Siyaset Bilimi ve Kamu Yönetimi Anabilim Dalı, Kamu Politikası Yüksek Lisans Programı tarikupeli@gmail.com, ORCID: 0000-0003-1988-7660
} 


\title{
Solidarity Rights of Environmental Rights and Development as a Private in Turkey Analysis
}

\author{
İmam Bakır KANLI ${ }^{4}$ İsmail Tarık KÜPELi ${ }^{5}$
}

Submitted by: 18.04 .2021

Accepted by: 31.05 .2021

Article Type: Review

\begin{abstract}
In the context of public administration discipline, and especially in the process of producing, implementing, and managing environmental policies, there has always been a struggle between public interest and personal interests. As a reflection of this struggle, the destruction of the physical environment affected not only nature or human beings negatively, but also the built environment. In particular during the last fifty years, the studies which were led by the United Nations have demonstrated that the stake holders who are parties to the problems acting in a sense of solidarity and cooperation as much as possible plays a key role in solving or minimizing environmental problems. Therefore, the solidarity took its place among the "Third Generation Rights" within the scope of environmental rights with the "Preliminary Draft of the Third International Pact on Solidarity Rights" in 1982. This study analyses the development of environmental rights as the right to solidarity in the world, its reflection and process in Turkey. In addition to its contribution to the literature, the article is considered to be important in terms of its contribution to the national and international studies of the central and local governments or to the environmental policies that they will produce. The study is limited by the United Nations, France and Turkey's policies on the environmental rights after 1970. In this study based on qualitative research method; the literature was reviewed, and data were obtained from the reports and analyses of national and international institutions and organizations along with the literature. The data obtained were evaluated with the document analysis technique and the study was concluded with the recommendations following the evaluation of the findings.
\end{abstract}

Keywords: United Nations, Environment, Environmental Right, Environmental Problems, Solidarity Rights

\footnotetext{
${ }^{4}$ Marmara University Faculty of Political Sciences, Department of Political Science and Public Administration, bkanli@yahoo.com, ORCID: 00000002-5715-8752

${ }^{5}$ Marmara University Institute of Social Sciences, Department of Political Science and Public Administration, Public Policy Master's Program, tarikupeli@gmail.com, ORCID: 0000-0003-1988-7660
} 


\section{Giriş}

Çevre, tarihsel süreç boyunca çeşitli çıkarlara bağlı olarak insanoğlunun her zaman ilgi odağında olmuştur. Özellikle 19. yy. sonları itibarıla neredeyse tüm alanlardaki paradigmaları değiştirecek güçte olan önemli buluşların gerçekleşmesi, bunun teknoloji ve üretim alanına yansımaları, kentsel nüfusu dalgalandırmakla kalmamış bu alanda yaşanan kentsel yığılma sürecini de arttırmıştır. Bunun bir sonucu olarak doğal ve yapılı çevre arasındaki denge ve taraflar arasında yaşanan mücadele, kişisel çıkarlar ve kamu yararı ekseninde gerçekleşmiştir. Doğal çevreye doğrudan ya da dolaylı olarak yapılan müdahalede ve bu bağlamda verilen mücadelede, bireylerin kişisel çıkarlarını en yüksek seviyeye çıkarmak istemesi, hegemonik anlayışa giden yolun yapı taşı olarak, başat bir güdüleme mekanizması olmuştur. Bu müdahale ilk başlarda; barınma, beslenme, güvenlik gibi temel ihtiyaçları karşılamak için olsa da zaman içerisinde sanayileşme gibi negatif dışsallık da içeren daha farklı hedeflerle kapsamını genişletmiştir. Ancak her ne kadar gerek sanayileşme süre,ci, gerekse teknolojik ve bilimsel gelişmeler, insanlığa ilk aşamada fayda sağlasa da, kalkınmada dengenin göz ardı edilmesi kamusal yararı zedelemiş, çevre sisteminin entropisinin artmasına neden olarak sadece yerel değil aynı zamanda bölgesel, ulusal ve küresel ölçekli yıkımların oluşmasına vesile olmuştur. Yaşanan bu sorunları çözmek için gerçekleştirilen küresel çabalarla çevrenin önemi ve önceliği bir kez daha ortaya konulmuş, gelecek kuşaklara yaşanabilir ve sağlıklı bir çevre bırakmak temel ilke olarak benimsenmiştir.

Çevre, sistemik özelliğinden dolayı, birbiriyle ilişkisi olan birçok alt sistemi içinde barındırır. Bu ilişkiler ağını bilmeden çevre sorunlarına kalıcı ve sürdürülebilir çözümler üretebilmek mümkün değildir. Alt sistemlerin çokluğu, çevre sorunlarına bütüncül bakışı da gerekli kılmaktadır. Bugün yaşanan sorunların karmaşıklığı içinde getirilen çözüm önerileri gün geçtikçe yetersiz kalmış ve bu durum, insan hakları içinde çevre hakkı olarak yeni bir kategorinin düzenlenmesi ve bu bağlamda da devletlerin işbirliği içinde hareket etmesinin gerekliliğini ortaya koymuştur. Birleşmiş Milletler (BM) tarafından gerçekleştirilen İnsan Çevresi (1972) adlı konferans, çevre hakkı konusundaki en önemli toplantılardan biridir. Zirvede, sağlıklı bir çevrede yaşama hakkı temel bir hak olarak müzakere edilmiş ve çevre hakkı kavramı, yayımlanan bildiriyle birlikte ilk kez insan hakkı olarak ele alınmıştır (UNEP, 2020).

İnsanoğlunun varlı̆̆ını sağlıklı bir şekilde sürdürebilmesi, içinde bulunduğu çevreye verdiği önem ile doğru orantılıdır (Şen, 1994, s. 33). Bu bağlamda çevre hakkını, sağlık ve yaşam hakkıyla ilişkilendirmek de mümkündür. Ancak ilke olarak, insan hakları birbirlerini tamamlayıcı bir özelliğe sahip olduğu için, çevre hakkının ilişkili olduğu haklar sadece sağlık ve yaşam hakkıyla sınırlandırılamamaktadır. Çolakoğlu (2010, s. 154) çalışmasında çevre hakkı için "temel insan haklarına erişmede önemli bir ön koşul”dur der. Bu bağlamda diğer insan haklarıyla olan yakın ilişkisi sebebiyle bu haklar içinde önemli bir yere sahip olduğu söylenebilir.

Bu çalışmanın amacı, çevre hakkının dayanışma hakkı olarak uluslararası mevzuattaki gelişiminini incelemek ve bu gelişimin Türkiye’ye olan yansımalarını analiz ederek, bu konuda alınan yolu ve gösterilen performansı ortaya koymaktır. Çalışmada insan hakkı, dayanışma hakkı ve çevre hakkı gibi temel kavramlar üzerinde durulmuş, bu kavramların birbirleriyle olan ilişkisi incelenmiştir. Diğer yandan, çevre hakkı kavramının uluslararası alandaki yeri ve gelişimi önce BM ve Fransa, daha sonra ise Türkiye özelinde, geçirilen süreç değerlendirilmiştir. Merkezi ve yerel yönetimlerin çevre hakkı konusunda yapacakları; yerel, ulusal ve uluslararası çalışmalara ve geliştirecekleri politikalara katkı sağlayacağı ve çevre hakkı konusunda literatüre yeni bir bakış açısı kazandırabilecek potansiyele sahip olduğu için bu çalışmanın önemli olduğu düşünülmektedir. Bu çalışma BM’nin, Türkiye'nin ve Fransa'nın 1970 sonrası çevre hakkı konusundaki önemli olarak görülen politikaları ve bu politikaların geçmişten beri süregelen etkileri ve nitelikleriyle sınırlandırılmıştır. Türkiye ile birlikte Fransa ülke örneğinin seçilmesinin en önemli nedeni, diğer ülkelerden farklı olarak, anayasasına çevre hakkına yönelik özel bir metni koymuş olmasıdır.

Bu çalışmada, olgu ve olayları, anlamak, yorumlamak ve sonrasında da bunları betimlemek isteyen, bu bağlamda da derinlemesine analiz etmeye olanak veren, (O’Leary, 2017, s. 148) bilimsel bir araştırma yöntemi 
olarak nitel araştırma paradigmasına dayalı bir yöntem tercih edilmiştir. Bu bağlamda literatür taraması yapılmış, literatür ile birlikte, nitel araştırmalarda önemli veri toplama yöntemlerinden biri olan doküman yoluyla; Türkiye İstatistik Kurumu, Birleşmiş Milletler Teşkilatı, Birleşmiş Milletler Avrupa Ekonomik Komisyonu ve EUROSAT gibi ulusal ve uluslararası kurum ve kuruluşların yayınladıkları rapor ve analizlerinden (Bowen, 2009, s. 27-28) yararlanılarak çevre hakkı bağlamında veriler elde edilmiştir. Elde edilen verilerin analizinde ise; başta basılı ve dijital belgeler olmak üzere konu ile ilgili tüm dokümanları analiz etmek ve değerlendirmek amacıyla kullanılan ve bu açıdan da sistematik bir teknik olarak değerlendirilen doküman analizi (belge analizi) tekniği (Kıral, 2020, s. 173) tercih edilmiştir. Analiz sonunda, çevre hakkı konusunda birçok çalışmanın gerçekleştirildiği fakat Türkiye özelinde yeterince çalışmanın bulunmadığı tespit edilmiştir. Elde edilen bulguların değerlendirmesini müteakip çevre hakkının geliştirilmesi ve yaygınlaştırılması adına sunulan önerilerle araştırma sonuçlandırılmıştır.

\section{Temel Kavramlar ve Teorik Çerçeve}

Bu bölümde, çevre hakkı kavramının daha iyi anlaşılabilmesi için öncelikle temel bileşenleri olan çevre ve insan hakkı kavramları açıklanmıştır. Çalışmanın devamında ise çevre hakkı kavramının düşünsel olarak incelenmesinde büyük rol oynayacak olan ve içinde bulunduğu hak grubu olması sebebiyle üçüncü kuşak haklar olarak da bilinen dayanışma hakkı kavramı irdelenmiştir. Sonrasında ise, açıklanan bu kavramların, birbiriyle olan pozitif ve negatif yönlü ilişkiler ağı, çevre hakkı kavramının geçirdiği değişim ve sürecin daha iyi anlaşılabilmesi amacıyla iki ayrı başlık altında analiz edilmiştir.

\section{İnsan Hakkı Olarak Çevre Hakkı}

Çevre hakkı kavramını irdelemeden önce, bu kavramın nüvesini oluşturan iki temel kavramdan biri olan, hak kelimesinin anlaşılması önemlidir. Uluslararası literatür incelendiğinde görülmüştür ki hak kavramını Feinberg (1970, s. 255) makul bir hak talebi olarak değerlendirirken Hohfeld (1919, s. 36) herhangi bir şarta bağlamadan bütün hakları bir talep olarak ele almıştır. Louden (1983, s. 95) ise hakkın taşıyıcısına verilen izin doğrultusunda yapabilme özgürlüğü olarak değerlendirmiştir. Gözler ${ }^{6}, \mathrm{Mumcu}^{7}$ ve Kaypak ${ }^{8}$ 'n dipnotta verilen hak tanımları ve diğer yazarların yaklaşımları farklı kelimelerle ifade edilmiş olsa da aslında hepsinin de ortak bir noktası bulunmaktadır. Bahsedilen ortak nokta, hakkın hukuk düzeni tarafından insanlara verilmesidir, başka bir bakış açısıyla hak, talep edilmesi gereken bir olgu niteliğine bürünmüştür. Özdek (1993, s. 88) bu duruma paralel olarak insan haklarının tümünde olduğu gibi, çevre hakkının temelinde de bir hak talebi olduğunu belirtmiştir.

Çevre hakkı kavramının diğer önemli bileşeni olan çevre ise, içinde muhtelif unsurları barındırması sebebiyle birden fazla tanımı olan bir kavramdır (Güneş ve Coşkun, 2004, s. 4). 11 Ağustos 1983 tarihli ve 2872 sayılı Çevre Kanunu ${ }^{9}$, Ekonomik İşbirliği ve Kalkınma Örgütü ${ }^{10}$ (OECD), Dünya Sağlık Örgütü ${ }^{11}$, Keleş $^{12}$, Chauhan ${ }^{13}$, Kanlı ve Kaplan ${ }^{14}$, Bilir ve Hamdemir ${ }^{15}$ tarafindan yapılan ve dipnotta da yer verilen tanımlar, her ne kadar

\footnotetext{
6 "Kişilere irade kudreti tanınmak suretiyle hukuk düzeni tarafından korunan menfaat" (Gözler, 2012, s. 154)

7 “Hukuk düzeninin kişilere tanıdığı yetki” (Mumcu, 2007, s. 12)

8 "Kişilerin yasa veya özel anlaşmalarla elde ettikleri yetki ve değerler" (Kaypak, 2009, s. 2)

9 "Canlıların yaşamları boyunca ilişkilerini sürdürdükleri ve karşılıklı olarak etkileşim içinde bulundukları biyolojik, fiziksel, sosyal, ekonomik ve kültürel ortam” (Çevre Kanunu, 1983)

10 “Bir organizmanın yaşamını, gelişimini ve hayatta kalmasını etkileyen tüm dış koşulların bütünü” (OECD, 2005)

11 “Dünya Sağlık Örgütü: İnsan dışındaki tüm fiziksel, kimyasal ve biyolojik faktörler” (Prüss-Ustün, Wolf, Corvalán, Bos ve Neira, 2016, s. 3).

12 "Canlıların yaşamlarını sürdürdükleri ortam" ve "Kişiyi etkileyen, maddi ve manevi olmayan gelişmesini, biçimlenmesini ve yaşamını belirleyen, biyolojik iklimle ilgili ve toplumsal etkenlerin tümü” (Keleş, 2013, s. 23)

13 “Organizmayı etkileyen her şey” (Chauhan, 2008, s. 1)

14 "Canlı ve cansız varlıkların bir arada bulundukları, farklı katmanları içerisinde barındıran ortam" (Kanlı ve Kaplan, 2019, s. 99)

15 “İnsanların ve diğer tüm canlıların içinde yaşadığı, birbirleriyle iletişim kurduğu, sosyal, kültürel, ekonomik, fiziksel ortam” (Bilir ve Hamdemir, 2011, s. 143)
} 
farklı açıdan farklı kelimelerle ele alınmışlarsa da, hak kavramında görüldüğü gibi hepsinin odak noktası insan ve onun etkileşimde bulunduğu dış çevresidir.

Çevre hakkı kavramını oluşturan kelime bileşenlerini kısaca inceledikten sonra çevre hakkı kavramına bakıldığında; Kara (2012, s. 91-92), kavramın ortaya çıkmasının temelinde; küresel ısınma, temiz su kaynaklarının israfı, doğaya zararlı enerji türlerinin tüketimi gibi özünde insan olan sebepler yattığını vurgular. Bir başka görüşe göre ise çevrecilik düşüncesinin, çevre hakkının temelini oluşturduğu kabul edilmektedir (Güveyi, 2018, s. 635). Tarlock (2009, s. 42)'a göre bu düşünce, insan ve doğa arasındaki ilişkiyi güne uygun bir şekilde anlamlandırmayı amaçlayan bir sistem olarak tanımlanabilir. Bu bağlamda, çevrecilik düşüncesinin temel olarak karşı olduğu insan-merkezci ve teknoloji-merkezci olmak üzere iki düşünce biçimi vardır (Öztürk, 2017, s. 443-444). İnsan-merkezci yaklaşım, Eckersley (2003, s. 51) tarafından “insanoğlu ve doğanın geri kalanı arasında ahlaken uygun bir ayrım çizgisi olduğu, insanoğlunun tek ya da temel değer ve anlam kaynağı olduğu, insan dışındaki doğanın da bu yüzden insanlığa hizmet etmek dışında hiçbir amacının olmadığı inancıdır" şeklinde ifade edilmiştir. Teknoloji-merkezcilik ise Carter (2007, s. 77) tarafından "toplumun tüm çevresel sorunlarını teknoloji ve bilimi kullanarak çözebileceğine ve sınırsız bir maddi gelişme sağlayabileceğine iyimserlikle inanılan düşünme tarzıdır” şeklinde tanımlanmıştır. Güveyi (2018, s. 635)'ye göre insanın sahip olduğu sorumluluklardan biri de doğayı korumasıdır ve bu görevi dolayısıyla insan doğaya zarar verme ihtimali olan bütün davranışlarını sınırlandırmalıdır. Bu sebeple çevrecilik ilkesiyle hazırlanmış olan çevre hukuku kuralları, gelecek kuşakların ve ekosistemin çıkarlarını ön plana alır.

İnsan hakları hukuku ve çevre hukuku, daha yaşanabilir bir dünyaya odaklanan ve bu amaca hizmet eden birbiriyle bütünleşik hedeflere sahiptirler. Bahsedilen iki kavram da evrensel düzeydeki olumsuzluklarla bireysel ölçekten küresel ölçeğe kadar mücadele etmektedir. Her ne kadar benzer, hatta kimi zaman da aynı hedeflere sahip olsalar da zaman zaman farklılaştı̆̆ı noktalar oluşmaktadır. İşte bu farklılaşmaları tamamlayıcı bir şekilde sürdürebilmek amacıyla ortak bir kavram etrafında toplanmak büyük kolaylık sağlayacaktır (Cullet, 1995, s. 25). Çevre hakkı, çevre kavramının çok faktörlü ve çok katmanlı yapısı ve özellikleri sebebiyle net bir tanımlamasının yapılmasına olanak sağlamamaktadır (Bilir ve Hamdemir, 2011, s. 143). BM’ye göre çevre hakkı “...temiz, güvenli, elverişli, sağlıklı ve ekolojik olarak dengeli...” bir çevreyi ifade etmektedir (UNEP, 2021). Uluslararası bir sivil toplum örgütü olan Uluslararası Yerküre Dostları'na (Friends of the Earth International) göre ise çevre hakkı, canlıların hayatta kalmasını sağlayan hava, yiyecek, su hatta barınak olmak üzere bozulmamış doğal kaynaklara erişebilme anlamına gelir. Bunun yanında el değmemiş bir doğa manzarasının keyfini çıkarabilme gibi daha saf ekolojik haklar da bu gruba dahil olabilmektedir (Friends of the Earth International, 2021). Çevre hakkı, Kaboğlu (1992, s. 18-30) tarafından iki şekilde tanımlanmıştır: bunlardan birincisi geniş anlamda olan "doğal ortam ve yaşam koşullarına olumsuz etki ve zararları önlemek ve cezalandırmak amacıyla özellikle devletlerin gerekli önlemleri alma, her insanın sağlıklı ve ekolojik olarak dengeli bir çevreye sahip olması için eşya ve malların kullanımını düzenleme yükümlülügü̈” şeklinde iken, ikincisi dar anlamda olan "sağlığın, beden bütünlüğünün ve yaşamın kendisinin korunma aracı" şeklindedir. Yapılan tanımlar göstermektedir ki çevre hakkı kavramsallaştırılırken esas alınan sağlıklı bir yaşamdır. Bununla birlikte kavramın, ele alan yazarın bakış açısına göre alt bileşenleri değişebilmektedir: kimi yazar sadece bireyi ve onun doğal çevresini ele alırken kimileri de daha geniş bir perspektiften değerlendirerek, devlet ve yasalar gibi olgularla eklemleyerek kavramı çok katmanlı bir noktaya taşımaktadır.

İnsan haklarına geldiğimizde, Donnelly (1995, s. 19) bu hakların, sadece insan olmaktan dolayı elde edilen hakları ifade ettiğini söyler. Amerikan Haklar Bildirisi (1776) ve Fransız İnsan ve Yurttaş Hakları Evrensel Bildirisi (1789)'yle resmi olarak ilk kez açıklanan insan hakları, tüm bireylerin doğumundan ölümüne kadar daima elinde olan haklarıdır ve bu, genel olarak kabul görmüş bir düşüncedir (The Declaration of the United States of America, 1776; Warman, 2016, s. 11-13). Kişilerin doğuştan etnik yapı, cins, din, dil, ırk farkı yapılmaksızın her zaman ve her koşulda eşit oldukları kabul edilmiştir. Fransız hukukçu Karel Vašák, insan 
haklarını kuşaklara göre sınıflandıran ilk kişidir. Teknolojik ve bilimsel ilerlemelerin insan onuruna karşı oluşturduğu tehdit, Vašák'in oluşturduğu ve üç gruptan oluşan haklara, dördüncü bir hak grubunun eklenmesi tepkisini ortaya çıkarmıştır (Vašák, 1977, s. 29-32; Boyar ve Kama Işık, 2019, s. 605).

Tablo 1

İnsan Hakkı Kuşakları İncelemesi

\begin{tabular}{c|c|c|c}
\hline HAKLAR & ZAMAN & TEMEL İLKELERİ & ÖRNEK \\
\hline Birinci Kuşak & 17. ve 18. yy. & Devredilemez, Dokunulamaz & Özel Hayatın Gizliliği \\
\hline İkinci Kuşak & 19. yy. & Sinıflar arası eşitliği sağlama & Grev hakkı \\
\hline Üçüncü Kuşak & 20. yy. & Dayanışma & Çevre Hakkı \\
\hline Dördüncü Kuşak & 20. yy. & İnsan onuru & Su Hakkı \\
\hline
\end{tabular}

Kaynak: Boyar ve Kama Işsk (2019, s. 605), (T.C. Anayasası, 1982), Dadak (2015, s. 311-313) ve Gündüzöz (2015, s. 23-25)'den faydalanılarak hazırlanmıştır.

Birinci kuşak haklar (klasik haklar), fikir özgürlüğü gibi daha çok bireyselliğe dayanan hakları kapsayan ve bunun yanında siyasi hakları da içeren bir kavramdır (Cornescu, 2009, s. 3). 17. ve 18. yüzyıllarda, ülkelerin anayasalarına girmeyi başarabilmiş (Uygun, 2000, s. 22) birinci kuşak haklar, koruyucu hakların ağırlıkta olduğu kuşaktır (Kaboğlu, 1998, s. 10). Koruyucu haklar, bireylerin devlet ve üçüncü kişiler tarafindan müdahale edilemeyecek, kişisel alanın hudutlarını belirleyen hak ve özgürlüklerdir. Örneğin Şekil 1'de yer alan hususlar koruyucu hak niteliğindedir. Negatif statü hakları olarak da adlandırılan bu haklar, devlete gölge etmeme sorumluluğu atfeder (Kapani, 1981, s. 230).

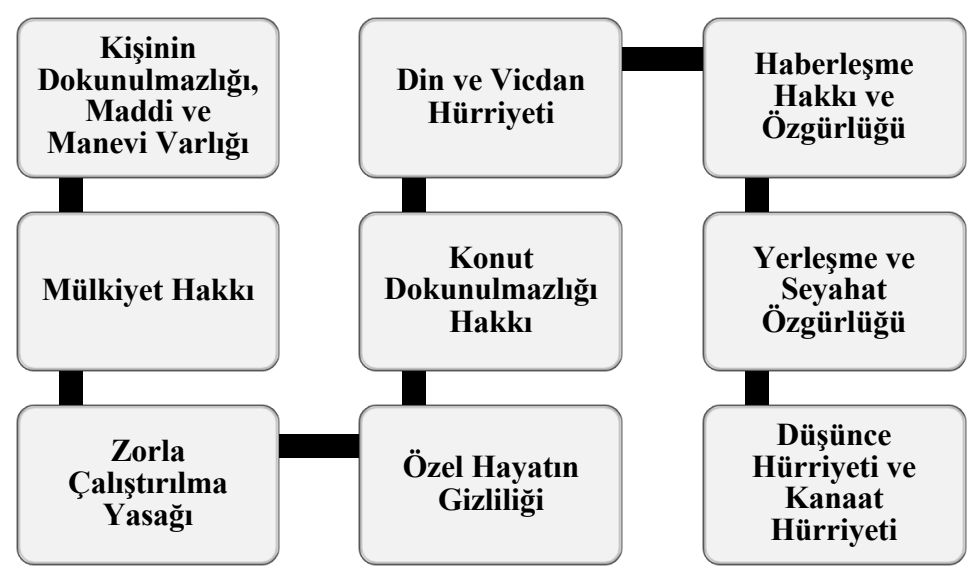

Şekil 1. 1982 Anayasası'nda Yer Alan Başlıca Klasik Haklar (T.C. Anayasası, 1982)'den faydalanılarak hazırlanmıştır.

Klasik haklardan sonra, sanayi devriminin sonuçlarından olan iktisadi ve toplumsal sorunlara tepki olarak oluşan ikinci kuşak haklar (sosyal haklar), insani şartlar altında yaşamını sürdürebilmenin temelini oluşturan toplumsal, iktisadi ve kültürel haklardır (Atar, 2007, s. 111). Pozitif statü hakları olarak da adlandırılan ikinci kuşak haklar, sosyal adaletsizliği ortadan kaldırmak, toplumsal ve ekonomik sorunları çözmek gibi sorumlulukları devlete yüklemektedir. Bu kuşaktaki haklara örnek Şekil 2'de verilmiştir. Birinci kuşak haklarda devletten pasif bir rol üstlenmesi beklenirken isteme haklarında bireyler arasında eşitliği sağlaması amacıyla 
özellikle müdahale etmesi beklenmektedir (Kapani, 1981, s. 51). Yapılan sınıflandırmada yer alan, dayanışma hakkı olarak da bilinen üçüncü kuşak haklar çalışmayla doğrudan bağlantısı olması sebebiyle ayrı bir başlık altında daha detaylı olarak değerlendirilmiştir.

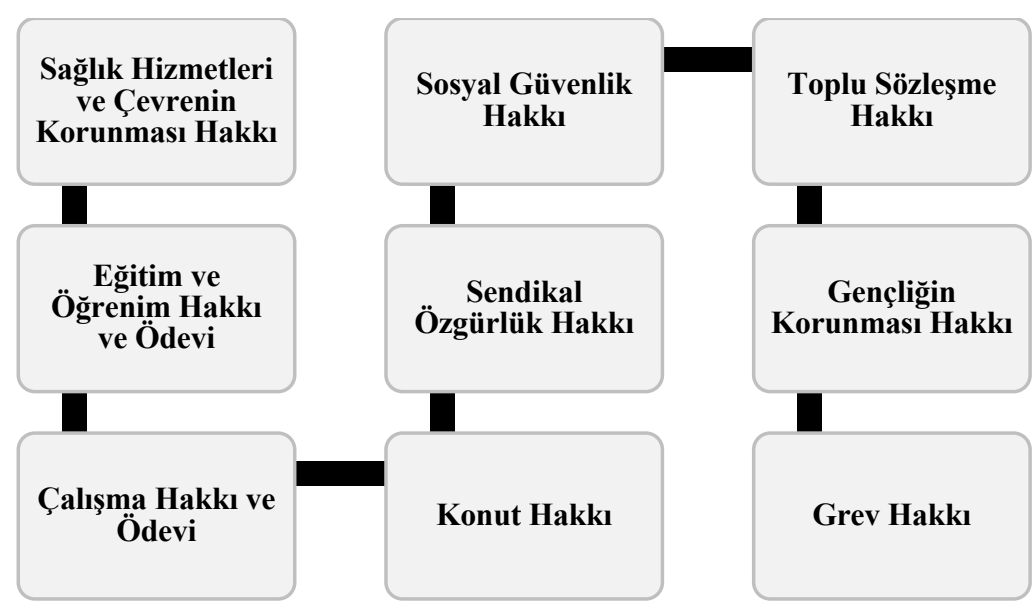

Şekil 2. Başlıca Pozitif Statü Hakları. (T.C. Anayasası, 1982)'den faydalanılarak hazırlanmıştır.

Karel Vašák tarafından yapılan, sınıflandırılmada bulunmayan fakat son zamanlarda gündeme gelen bir diğer grup ise dördüncü kuşak insan haklarıdır. Dünya da resmi olarak böyle bir hak tanımı henüz yapılmamıştır, sadece atılan küçük adımlar görülmektedir (Aykul, 2015). Örneğin BM tarafından su hakkı tanımlanmış olmasına rağmen herhangi bir uluslararası sözleşmede bu hak teminat altına alınmamıştır (Topçu, 2008, s. 16). Bunun yanında Cornescu $(2009$, s. 8) ötenazi ve ceninin durumu gibi bazı dördüncü kuşak insan haklarının ulusal ve uluslararası metinlerde düzenlendiğini belirtmiştir. Gündüzöz (2015, s. 25) son 20 yılda ortaya çıktığını belirttiği dördüncü kuşak haklara biyoetik haklar gibi konuları örnek olarak gösterirken, Gülmez (2001, s. 22) ise çalışmasında insan onuruna saygı ve su hakkı gibi konuları ele almıştır. Başka bir çalışmada ise dördüncü kuşak haklara, kent hakkl, ekosistem hakkı gibi haklar örnek olarak gösterilmiştir ve bu kuşaktaki hakların öznesi birey olmadığı için doğrudan temel insan hakkı olarak kabul edilmemiştir (Aykul, 2015). Farklı çalışmaların içeriği incelendiğinde dördüncü kuşak hakların ortak bir tanımının veya kapsamının henüz belirlenemediği görülmektedir.

Elde edebilmek için çok fazla emek ve zamanın harcandığı insan hakları, günümüzde büyük bir tehditle karşı karşıyadır. Endüstri 4.0’’n tüm paradigmaları değiştirmesi, buna bağlı olarak bilişim teknolojilerindeki gelişmeyle son dönemde dünya genelinde yaşanan COVID-19 salgını, her alanda yaşamın merkezine dijitalleşmeyi yerleştirmeye başlamıştır. Bireysel en küçük işlemlerden devlet politikalarına kadar geniş bir kullanım alanına sahip olan kavramın insan hakları konusunda da etkisini göstermesi kaçınılmazdır. Bu bağlamda; veri mahremiyeti, kişisel verilerin korunması gibi konular tehdit olarak ortaya çıkabilmektedir. $\mathrm{Bu}$ tehditlere tepki olarak bilim ve teknolojinin gelişmesiyle birlikte değişen şartlar, insan haklarını değişime zorunlu tutacak ve bunun yanında unutulma hakkı gibi kavramları ortaya çıkarmaya devam edecektir (Elmalıca, 2016, s. 1610; Eroğlu, 2018, s. 131) 


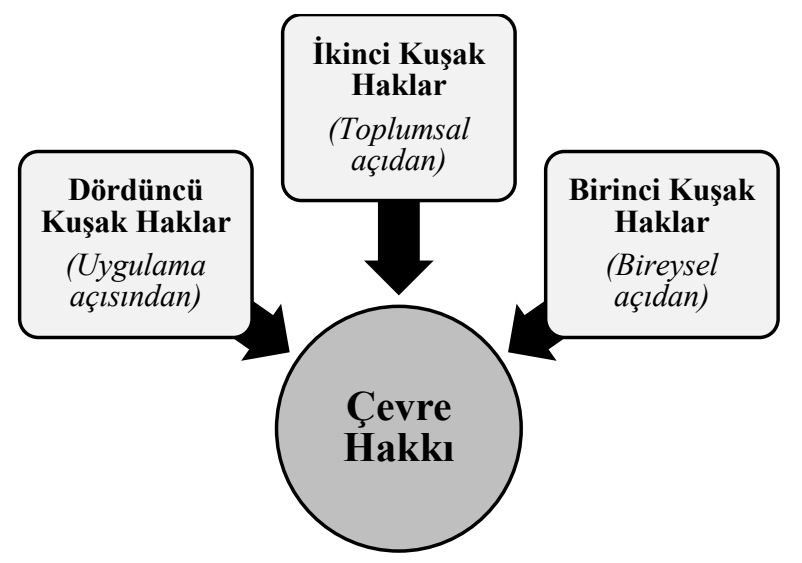

Şekil 3. Çevre Hakkı ve Kuşaklar Arasındaki İlişki

Şekil 3'te görüldügü gibi, çevre hakkının insan hakkı kuşaklarıyla temel ilkeleri başta olmak üzere çeşitli açılardan doğrudan ilişkisi bulunmaktadır. Öncelikle uygulama açısından değerlendirildiğinde kendisinin de dahil olduğu üçüncü kuşak haklar grubunun yanı sıra dördüncü kuşak hak grubuyla da öznesinin insan olmaması sebebiyle benzerlik göstermektedir. Bir diğer bağlantı ise temel ilkeleri doğrultusunda ortaya çıkmaktadır. Toplumsal açıdan yapılan analizde ise çevre hakkıyla ikinci kuşak haklar arasında bağlantı kurulmaktadır. Bunun iki temel göstergesi vardır. Bunlardan ilki çevre hakkının ikinci kuşak hakların genelinde olduğu gibi dayanışma temelli olmasıdır. İkinci gösterge ise isteme haklarında devletin aktif rol üstlenmesidir. Çevre hakkının da sağlıklı bir şekilde sürdürülebilirliğinin ${ }^{16}$ sağlanması için bir aktör olarak devletin de rol alması gerekmektedir. Son olarak ise, bireysel açıdan birinci kuşak haklara sıkı sıkıya bağlıdır. Bunun sebebi olarak iki konu gösterilebilir bunlardan birincisi klasik hakların dokunulmazlık özelliğidir. Öyle ki, sağlıklı bir çevrede yaşamak bir haktır (World Resources Institute, 2021) ve bu hak hiçbir şekilde engellenemez. İkinci konu ise birinci kuşak hakların bireyselliğidir. Her ne kadar çevre hakkı dayanışma temelli olsa da bireysel olarak ele alınmadığında ve korunmadığında beklenildiği gibi gelişme gösteremeyecektir. Çeşitli toplumsal, ekonomik, teknolojik ve bilimsel gelişmeler, Şekil 3’te yer verilen haklar arasındaki bağ etkilemektedir, dolayısıyla bu bağ her zaman eşit olmayabilir. Örneğin, bilimsel yenilikler çevre hakkının uygulanabilirliği konusunda güçlü gelişmeler oluşturabilirken, diğer taraftan toplumsal ve ekonomik olaylar çevre hakkının zedelenmesine sebep olabilmektedir. Yukarıda yer verilen ilişki, çevre hakkının gelişmesi açısından büyük önem taşımaktadır. Bu sebeple aralarındaki bağlantının güçlü tutulması ve geliştirilmesi için çalışmaların yapılmasına ihtiyaç duyulmaktadır.

\section{Çevre Hakkı ve Dayanışma Hakkı ilişkisi}

Hak kavramının çok kapsamlı ve bileşenli bir yapıya sahip olması onun çeşitli özelliklere göre farklı gruplara ayrılmasını zorunlu kılmıştır. Bu gruplandırma hak kavramının kapsadığı olguları daha iyi analiz edebilmek açısından önemlidir. Üçüncü kuşak hakların ortaya çıkmasına zemin hazırlayan birçok unsur vardır fakat bunların hepsini tetikleyen asıl konu bilimsel ve teknolojik gelişmelerin ortaya çıkarmış olduğu toplumsal ve ekonomik sorunlardır (Başlar, 2001, s. 34). Bu kuşaktaki hakların en önemli özelliği ise bireyselliğin ötesinde toplumsal bir nitelik taşımasıdır (Hamamc1, 1983-1984, s. 177), bunun yanında ulusal sınırları aşıp uluslararası bir nitelik taşıdığı da söylenebilir (Özdek, 1993, s. 29-39). Üçüncü kuşak hakların uygulanması kolektif bir çabaya bağlıdır ve bütün insanları ilgilendiren bir konudur, bu yüzden dayanışma hakları olarak da adlandırılır (Kaypak, 2017, s. 5).

\footnotetext{
${ }^{16}$ Çevre hakkı ve sürdürülebilirlik arasındaki ilişki iki kavramın da mekânsal ve zamansal sınırlarının olmamasına Özdek (1993, s. 91-92) dayanmaktadır. Çevrenin korunması ve bir hak olarak değerlendirilmesi bugünkü ve gelecek kuşakları aynı anda kapsaması açısından sürdürülebilirlik kavramıyla örtüşmektedir (Olgun ve Işık, 2017, s. 45).
} 


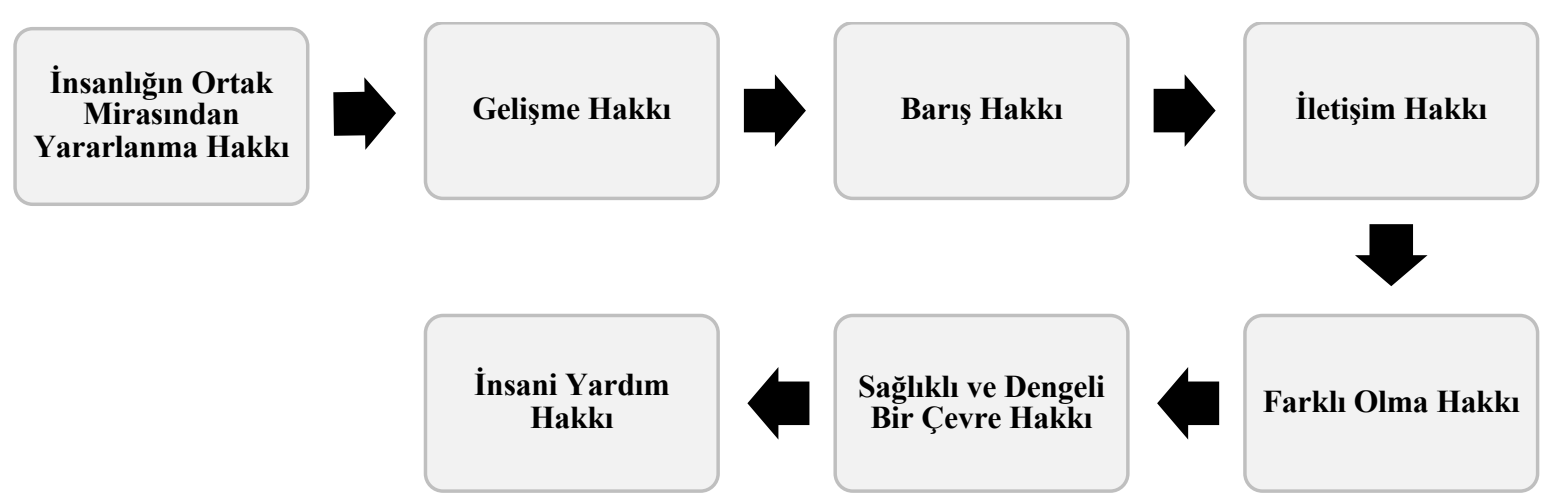

Şekil 4. Alston’a Göre Üçüncü Kuşak Haklara Dahil Edilmek İçin En Çok Önerilen Haklar.

Alston (1982, s. 307-308)'dan faydalanılarak hazırlanmıştır.

Dayanışma haklarının ortaya çıkmasındaki en önemli sebepler, toplumsal değerleri ve dayanışma duygusunu geliştirebilecek ortamı sağlamaktır (Özdek, 1993, s. 91). Bu kuşaktaki haklarda devletin ve bireylerin ortak bir sorumluluğu olmakla birlikte bireyler sürece aktif bir şekilde katılarak dayanışma özelliğine vurgu yapmakla da yükümlüdürler (Ceylan, 2019, s. 15). Şekil 4’te Alston'a göre üçüncü kuşak haklara dahil edilmek için en çok önerilen hakları göstermektedir. BM tarafından 1982 yılında Dayanışma Haklarına İlişkin Uluslararası Üçüncü Pakt Ön Tasarısı'yla birlikte dört hakkın düzenlendiğini belirtmiştir. Bunlar: insanliğın ortak malvarlığına saygı hakkı, barış hakkı, gelişme hakkı ve çevre hakkı olarak sıralanmıştır (Atar, 2013'ten aktaran Aydoğdu, 2017, s. 46).

Çevre hakkı nitelik açısından çok ögeli olması ve gelecek nesilleri de kapsaması sebebiyle üçüncü kuşak hak grubundadır. Bu hak teorik olarak kabul edilse bile uygulamada çeşitli zorluklarla karşılaşabilmektedir. Bunun en büyük sebebi, mekânsal ve zamansal ögelerin yokluğudur (Özdek, 1993, s. 91-92). Belirli bir sınırı ve etki alanı olmaması da uygulama aşamasında önemli sorunları getirebilmektedir (Kaypak, 2017, s. 9). Kavram, kapsam olarak hem geleceği hem de bugünü içerdiği için doğal çevrede oluşması muhtemel olan yıkımlar, gelecek nesilleri de etkileyecektir (Abdulhekimoğulları, Sezer ve Akpınar, 2011, s. 65).

Çevre hakkı; kapsamı, öznesi, etki alanı gibi özellikleri sebebiyle her ne kadar dayanışma hakları içinde yer alsa da diğer kuşaklardaki haklarla da yakından ilişkilidir. Kavram, birçok ulusal ve uluslararası belgeye konu olmasına rağmen, mevcut sorunları tamamen ortadan kaldırabilecek etkinliğe henüz ulaşamamıştır. Bunun sebebi olarak kapsamının çok geniş olması ve başlangıcının çok eskilere dayanmaması gösterilebilir. Fakat gerçekleştirilen çalışmalar çevre hakkı konusunda bilincin hızla geliştiğini, özellikle son zamanda yaşanan küresel boyuttaki sağlık sorunları ve çevresel tahribatın bu konuda etkili olduğunu göstermektedir. 
Tablo 2

Dayanışma Hakları ve Çevre Hakkı Karşılaştırması

\begin{tabular}{|c|c|}
\hline DAYANIŞMA HAKLARI & ÇEVRE HAKKI \\
\hline OLUŞUM SEBEPLERİ & OLUŞUM SEBEPLERİ \\
\hline $\begin{array}{l}\text { (a) Toplumsal ve ekonomik sorunlar (Başlar, 2001: 34). } \\
\text { (b) Toplumsal değerleri ve dayanışma duygusunu } \\
\text { geliştirebilecek ortamı sağlamak (Özdek, 1993: 91). }\end{array}$ & $\begin{array}{l}\text { (a) Özünde insan olan çevresel sorunlar (Kara, 2012: 91- } \\
\text { 92). } \\
\text { (b) Çevrecilik düşüncesi (Güveyi, 2018: 635). }\end{array}$ \\
\hline KARAKTERİSTİKLERİ & KARAKTERİSTİKLERİ \\
\hline $\begin{array}{l}\text { (a) Bireyselliğin ötesinde toplumsal bir niteliktedir } \\
\text { (Hamamcı, 1983-1984: 177). } \\
\text { (b) Uluslararası bir niteliktedir (Özdek, 1993: 29-39). } \\
\text { (c) Kolektif bir çabaya bağlıdır (Kaypak, 2017: 5). } \\
\text { (d) Temel unsurları devlet ve bireydir (Ceylan, 2019: } \\
\text { 15). }\end{array}$ & $\begin{array}{l}\text { (a) Mekânsal ve zamansal ögeleri yoktur (Özdek, 1993: } \\
\text { 91-92). } \\
\text { (b) Belirli bir sınırı ve etki alanı yoktur (Kaypak, 2017: } \\
\text { 9). } \\
\text { (c) Temel unsurları açısından çok ögelidir (Özdek, } \\
\text { 1993: 91-92). } \\
\text { (d) Nesilleri arası etkileşim (Abdulhekimoğulları, Sezer } \\
\text { ve Akpınar, 2011: 65). }\end{array}$ \\
\hline
\end{tabular}

Çevre hakkı ve dayanışma hakkı kavramları oluşum sebepleri ve karakteristikleri açısından incelendiğinde Tablo 2'de görülmektedir ki, birbirini tamamlayıcı hatta yer yer aynı çerçevede olabilmektedir. Oluşum sebeplerinin benzerliği, etki alanlarının genişliği, birden fazla paydaşa ve onların dayanışmasına ihtiyaç duymaları gibi özellikleri sebebiyle bu iki kavram birbirine sıkı sıkıya bağlıdır. Çevre hakkının neden dayanışma hakları kapsamında olduğunun bir göstergesi olan bu tablonun, iki kavram arasındaki ilişkinin anlaşılmasında olumlu rol oynayacağı düşünülmektedir.

\section{Uluslararası Alanda Çevre Hakkı Olgusu ve Fransa Örneği}

Yukarıda da vurgulandığı gibi, gerek ulusal gerekse uluslararası politikaları etkileme gücüne sahip olan çevre sorunları, özellikle 1970’lerden günümüze kadar küresel ölçekte gündemde kalmayı başarmıştır. Ülkeler bu sorunları gidermek ve buna hukuki bir güvence sağlamak amacıyla bir araya gelerek hareket etmekte, buna yönelik anayasal düzenlemeler, politikalar ve konferanslar gerçekleştirip antlaşmalar yapmaktadırlar (Çolakoğlu, 2010, s. 153; Keleş ve Ertan, 2002, s. 40.).

Keleş (1994, s. 276) çevre hakkının çağdaş anayasalara girmesinin 1970'li yıllara denk geldiğini belirtir. Buradan hareketle çevrenin bir hak olarak kabul edilmesinin çok eskilere dayanmadığı çıkarımına varılabilir. İnsan Hakları Evrensel Bildirisi (1948), gibi insan hakları konusunda yapıtaşı sayılabilecek belgelerde bile çevre hakkından söz edilmemiştir. Bunun sebebi olarak, belgelerin hazırlandığı süreçte henüz çevresel sorunların büyüklüğü ve önemi konusunda yeterli bir toplumsal bilince sahip olunmaması gösterilebilir (Boyd, 2012, s. $3)$.

Çevrenin bir hak olarak uluslararası belgelerde yer alması BM İnsan Çevresi Bildirisi'yle (1972) gerçekleşmiştir (UNEP, 2020). Yayınlanan bildirinin ilk maddesinde, insanoğlunun varlığını kaliteli bir şekilde devam ettirebilmesinin yaşadığı çevrenin sağlıklı bir şekilde korunmasıyla doğru orantılı olduğu ve hem şimdiki nesillerin hem de gelecek nesillerin bu hakka ortak olduğu belirtilmiştir (Güneş ve Coşkun, 2004, s. 56). BM bünyesinde çevre çalışmalarını gerçekleştirmek ve eşgüdümü sağlamak amacıyla İnsan ve Çevresi 
Deklarasyonu (1972) doğrultusunda, BM Çevre Programı (UNEP) kurulmuş ve sürdürülebilir kalkınma yaklaşımı ilk defa gündeme getirilmiştir (Egeli, 1996 aktaran Bilir ve Hamdemir, 2011, s. 144).

Çevre hakkı açısından önemli bir diğer konferans ise 1992 yılında gerçekleştirilen BM Çevre ve Kalkınma Konferansı'dır. Çevre alanında birçok çalışmanın yapıldığı bu konferansın hedeflerinden biri, BM İnsan Çevresi Bildirisi'nin hayata geçirilmesidir. Bu doğrultuda küresel boyutta yeni iş birliklerinin kurulabilmesi için devletler ve sivil toplum örgütleri gibi yapıların önemi vurgulanmıştır. Bunun yanında, küresel ölçekte çevrenin korunması için gerekli düzenlemeler yapılmış ve dünyadaki kaynak israfını önlemek için uluslararası işbirliğinin önemine dikkat çekilmiştir (Özmehmet, 2008, s. 8). Konferans sırasında Rio Bildirisi, Orman İlkeleri, Gündem 21, BM İklim Değişikliği Çerçeve Sözleşmesi ve BM Biyolojik Çeşitlilik Sözleşmesi (T.C. Dişişleri Bakanlığı, 2020a) gibi önemli fakat bağlayıcılığı bulunmayan metinler yayımlanmıştır.

Rio Konferansı'ndan sonra yaşanan on yıllık süreç, tüketim ağılıklı davranışların artması, biyolojik çeşitliliğin gittikçe azalması, enerji tüketimi ve gelir eşitsizliğindeki artış gibi birçok başarısızlık barındırır (Glass, 2002, s. 97). Rio+10 Zirvesi, 1992-2002 yılları arasında geçen sürecin değerlendirmesi ve geleceğe yönelik kalkınma stratejilerini belirlemek hedefiyle gerçekleştirilmiştir (A ğca, 2002). Konferansı önemli kılan sebep, toplumun farklı kesimlerinin hazırlık sürecine ve toplantılara katılabilmesine sağlanan önceliktir. Bu doğrultuda zirve, sivil toplum kuruluşları (STK), yerel yönetimler ve özel sektör gibi birçok toplumsal aktörün katılımıyla gerçekleştirilmiştir (Özmehmet, 2008, s. 10-11). Zirve'nin amacı, BM Çevre ve Kalkınma Konferansı'nda kabul edilen, fakat yürürlüğe alınması için gerekli adımların atılmadığı ilkelerin gerçekleştirilmesine yönelik çalışmaların planlanmasıdır (Güneş, 2012, s. 88). Konferansa katılım sağlayan ülkeler, 1992-2002 yılları arasında yaptı̆̆ çalışmaları ve geleceğe yönelik önerileri içeren birer Ulusal Rapor hazırlayarak Rio+10 Zirvesi’ne sunmuşlardır (Ağca, 2002).

Konferans genelinde asıl kaygının ekonomik kalkınmaya yönelik olması ve çevrenin, ekonomik kalkınmanın sağlanabilmesi için bir araç olarak görülmesi bunun yanında çevre hakkına ve çevrenin öz değerine yer verilmemesi birçok eleştiriye sebep olmuştur (Bozkurt, 2019, s. 61; Semiz, 2016, s. 28). Bahsedilen olumsuzlukların yanında konferans, çevre hakkı kapsamında bazı önemli sonuçlara da aracı olmuştur. Bunlardan en önemlisi daha önce çevre hakkına yönelik hazırlanmış olan antlaşmalara, birçok ülke Rio+10 Zirvesi'yle birlikte taraf olmuştur (Güneş, 2012, s. 89).

Çevre konusuna yer verilen sonuncu toplantı STK'ların, üst düzey yöneticilerin ve devlet yöneticilerinin katılımıyla 2012 yılında gerçekleştirilen Rio+20 Zirvesi'dir. Ana hedefi, sürdürülebilirlik ile çevresel sorunlarla mücadele arasındaki ilişkiyi güçlendirmek (T.C. Çevre ve Orman Bakanlığı, 2020; İstediğimiz Gelecek, 2012, s. 1) olan konferans sonunda, 39. maddesi çevre hakkıyla bağdaştırılan, İstediğimiz Gelecek (Future We Want) başlıklı bir sonuç bildirgesi yayımlanmıştır. Bu belgeyle birlikte, daha önceki konferanslarda hazırlanmış olan metinlerin yeniden onaylandığı ifade edilmiştir. Bunun yanında Konferans sonunda yayımlanan bildiri, genel olarak BM’nin yayımladığı önceki bildiriler gibi insan-merkezci ve ekonomik kalkınmayı önceleyen bir metin olmuştur. Ancak ekonomik kalkınmanın çevreyi korumadan sağlanamayacağına da değinilmiştir (Semiz, 2016, s. 29).

Yapılan konferansların yanında insan hakkı açısından önemli bazı metinler vardır. Bunlardan ilki, San José Paktı olarak da bilinen 22 Kasım 1969 tarihli Amerika İnsan Hakları Sözleşmesi'dir (United Nations Treaty Collection, 2020). İktisadi, toplumsal ve kültürel haklar alanında sözleşmeye ek olarak dahil edilen San Salvador Protokolü (Protocol of San Salvador) içinde bulunan 11. Madde ("Herkes sağlıklı bir çevrede yaşama ve temel kamu hizmetlerine erişim hakkına sahiptir”) ile çevre hakkına değinilmiş ve çevrenin korunması yükümlülüğü devletlere atfedilmiştir (Organization of American States, 2020).

Çevre hakkı kapsamında önemli sayılabilecek bir diğer metin 27 Haziran 1981 tarihli Afrika İnsan ve Halkların Hakları Şartı'dır (African Union, 2020). Belge çevre hakkı açısından incelendiğinde, iki önemli özellik 
taşımaktadır. Bunlardan birincisi çevre hakkının öznesi olarak halklar kabul edilmiştir. İkincisi ise ekonomik olarak güçsüz ülkelere yönelik olmasıdır (Semiz, 2016, s. 30). Adı geçen metin gerek çevre açısından gerekse insan haklarının uluslararası alanda hukuki bir zemine kavuşmasına destek olması bakımından önemli bir belgedir. Şartın bölgesel bir nitelik taşımasına rağmen çevre hakkı konusunda bağlayıcı ilk belge olması ve bunu açık açık dile getirmesi sebebiyle uluslararası çevre hukukunun gelişmesine büyük katkı sağlamıştır (Bozkurt, 2019, s. 67).

Çevre hakkının etkili bir şekilde yerine getirilebilmesi için bazı diğer haklar tarafından teminat altına alınması ve bu hakların araç olarak kullanılması gerekmektedir. Bu haklar prosedürel ya da usuli haklar olarak adlandırılan katılma hakkı, başvuru hakkı, bilgi edinme ve haber alma hakkı olarak sayılabilir (Olgun ve Işık, 2017, s. 39 ve 42). Bahsedilen haklarla çevre hakkının ilişkisine dair ilk belge olan Dünya Doğa Şartı (World Charter for Nature), otuz dört gelişmekte olan ülkenin desteğiyle 29 Ekim 1982'de BM Genel Kurulu'nda kabul edilmiştir (Wood, 1985, s. 977). Şartın 23. İlkesinde, çevre hakkının katılma hakkıyla olan ilişkisine açık bir şekilde vurgu yapılmıştır (Refworld, 2020).

Çıkış noktası kalkınma ve çevre arasındaki yaşanan uyumsuzluğun sürdürülebilir kalkınmayla giderilebileceği fikri olan (Keleş ve Ertan, 2002 aktaran Mutlu, 2011, s. 43) Brundtland Raporu, 1983 yllında Dünya Çevre ve Kalkınma Komisyonu tarafından hazırlanmıştır. Sürdürülebilir kalkınma, ilk kez bu raporda "Bugünün gereksinimlerini, gelecek kuşakların gereksinimlerini karşılama yeteneğinden ödün vermeden karşılayan kalkınma" şeklinde tanımlanmıştır (T.C. Dışişleri Bakanlığı, 2020a). Sürdürülebilir kalkınma; çevre, ekonomi ve toplum arasında var olan uyumun ve karmaşık bağlantıların anlaşılmasını ve bunlara göre hareket edilmesini içerir (Drexhage ve Murphy, 2010, s. 6). Burada bahsedildiği gibi raporda da çevre ve ekonominin ayrılamaz iki alan olduğu belirtilmiştir. Ortak Geleceğimiz Raporu kısaca çevresel sorunları tespit etmekte, kalkınmanın ekonomi hariç başka boyutlarının da olduğuna dikkat çekmekte ve direkt olarak olmasa da nesiller arası adalet konusunda farkındalık yaratmaktadır. Sürdürülebilir kalkınma, raporun yayımlanmasından sonra sık sık çevre hukuku alanında kullanılmaya başlanmıştır (Semiz, 2016, s. 24-25).

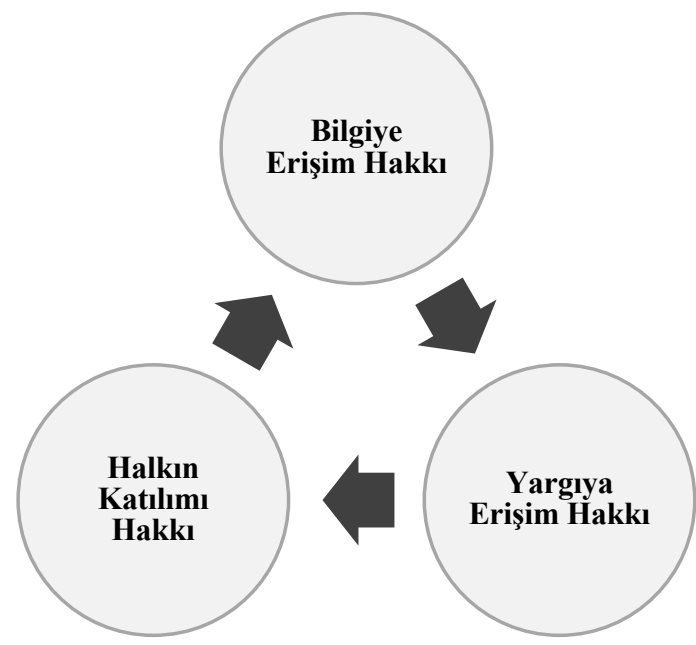

Şekil 5. Aarhus Sözleşmesi’nin Dayandığı Usuli Haklar. Güneş ve Münster (2010, s. 328-

329)'den faydalanılarak hazırlanmıştır.

Çevre hakkı bağlamında küresel ölçekte yapılan çalışmalardan biri olan ve Çevresel Konularda Bilgiye Erişim, Kamunun Katılımı ve Yargıya Başvuru Sözleşmesi olarak da bilinen Aarhus Sözleşmesi, UNECE (United Nations Economic Commission for Europe) tarafından 1998 yllında kabul edilmiştir (UNECE, 2020). Metnin giriş kısmında şimdiki ve gelecek kuşakların çevreyi koruma yükümlülüğü ve herkesin yaşamını sağlıklı ve 
dengeli bir çevrede sürdürme hakkının bulunduğu özellikle belirtilmiştir. Adı geçen belge, çevresel konuların yanında devletler açısından şeffaflık, hesap verilebilirlik ve çevresel yükümlülüklere de değinmiştir (Erdoğan, 2016, s. 1813). Sözleşme, Şekil 5’te de vurgulanmış olan konulara ayrıntılı olarak yer verilen ilk uluslararası belgelerden biridir (Güneş ve Münster, 2010, s. 328).

Yukarıda da bahsedildiği gibi küresel ölçekte yaşanan sorunların çözümüne yönelik bir çok konferans ve uluslararası sözleşmeler düzenlenmiştir. Ancak atılan adımların, çevre koruma için geliştirilen politika ve toplum bilincinin, özellikle de merkezi yönetimler tarafından ayrılan bütçenin yeterli olmadığı görülür. Grafik 1'de AB'ye üye ülkelerin 2018 yılında yaptığı çevresel harcamaların gayri safi yurtiçi hasılaya (GSYİH) oranı, Avrupa Birliği $(\mathrm{AB})$ ortalamasının $(\% 0,8)$ üstünde olan sekiz ülke (Hollanda, Belçika, Yunanistan, Malta, Fransa, Çek Cumhuriyeti, İspanya ve Lüksemburg) verilmiştir. Türkiye’nin ise toplam çevre koruma harcamalarının bu yılda GSYİH'ye oranı \%1 iken sadece hükümet harcamaları Türkiye'nin sahip olduğu orandan fazla olan ülkelerin bulunması dikkat çekicidir (Eurostat, 2021; TÜİK, 2020).

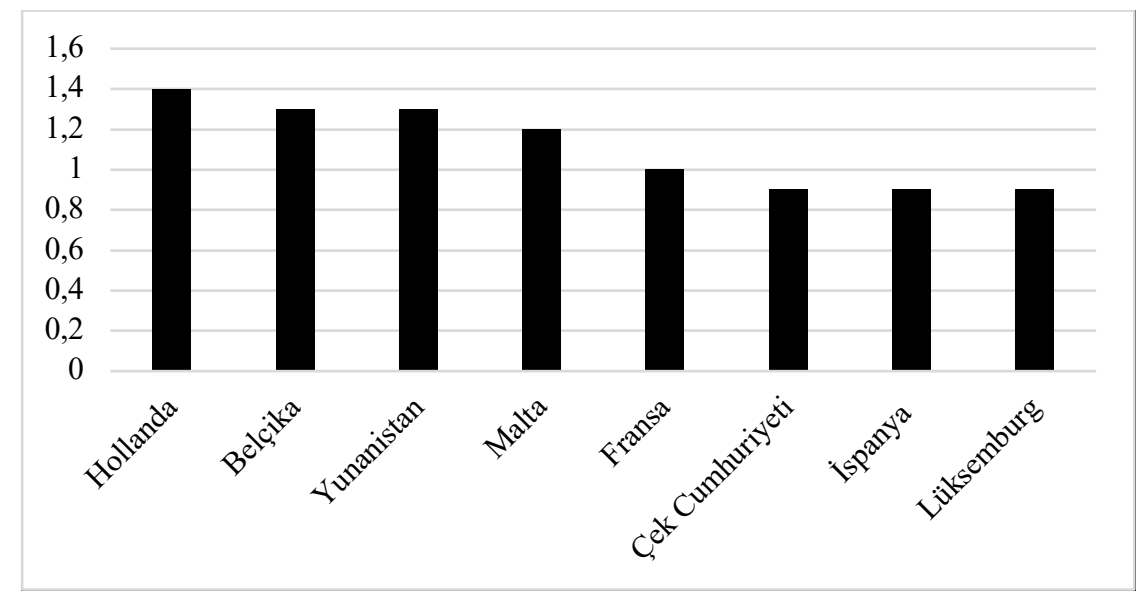

Grafik 1. Hükümetlerin Çevresel Harcamalarının GSYİH'ye Oranı. Eurostat'dan faydalanılarak hazırlanmıştır (Eurostat, 2021).

Kısaca değerlendirmek gerekirse; çevresel konularda hareketlenmelerin başlaması 1945 sonrası döneme denk gelmekle birlikte 1970'li yıllar çalışmaların yoğunlaştığı dönem olmuştur. Günümüzde de küresel boyutta yükselerek devam etmektedir (Güveyi, 2018, s. 642). Yukarıda bahsedilenler dışında uluslararası alanda çevreyle ilgili AB'nin uygulamaya koyduğu eylem programları, yapılan uluslararası toplantılar, konferanslar ve bildiriler de mevcuttur. Çevre konusunda yapılan çalışmaların dünyanın durumu göz önüne alındığında artarak devam edeceği öngörülebilir (Bilir ve Hamdemir, 2011, s. 144).

Hukuki anlamda bir bağlayıcılığı olmayan uluslararası sözleşme, konferans ve belgelerle sadece siyasi bir taahhüt altına giren ülkeler, şartların uygun olduğu durumlarda ulusal hukuk düzenlemelerini ve çevre politikalarını verilen taahhütler doğrultusunda şekillendireceklerini belirtmişlerdir (Yurtcanlı, 2012, s. 310). Özellikle 1990'lı yılların başından itibaren dünya genelinde, sağlıklı ve temiz bir çevre konusunda 100'den fazla anayasada gerek doğrudan gerekse dolaylı olarak bireye ve devlete sorumluluk atfedilmiştir ve söz konusu anayasaların yüzde elliden fazlası, Fransa da dahil olmak üzere, çevre hakkını açık bir şekilde tanımlamaktadır (Çolakoğlu, 2010, s. 155). Fransa, günümüze kadar Aarhus Sözleşmesi (Bozkurt, 2019, s. 79) ve Şekil 6' da yer alan Ozon Tabakasının Korunmasına Dair Viyana Sözleşmesi, gibi birçok uluslararası çevresel belgeye taraf olmuş ve konferanslara katılmıştır. Zaman içerisinde bu faaliyetler doğrultusunda ulusal çalışmalar düzenlenmiş ve belki de bunlardan en önemlisi Çevre Şartı olmuştur (Charte de l'environnement). 


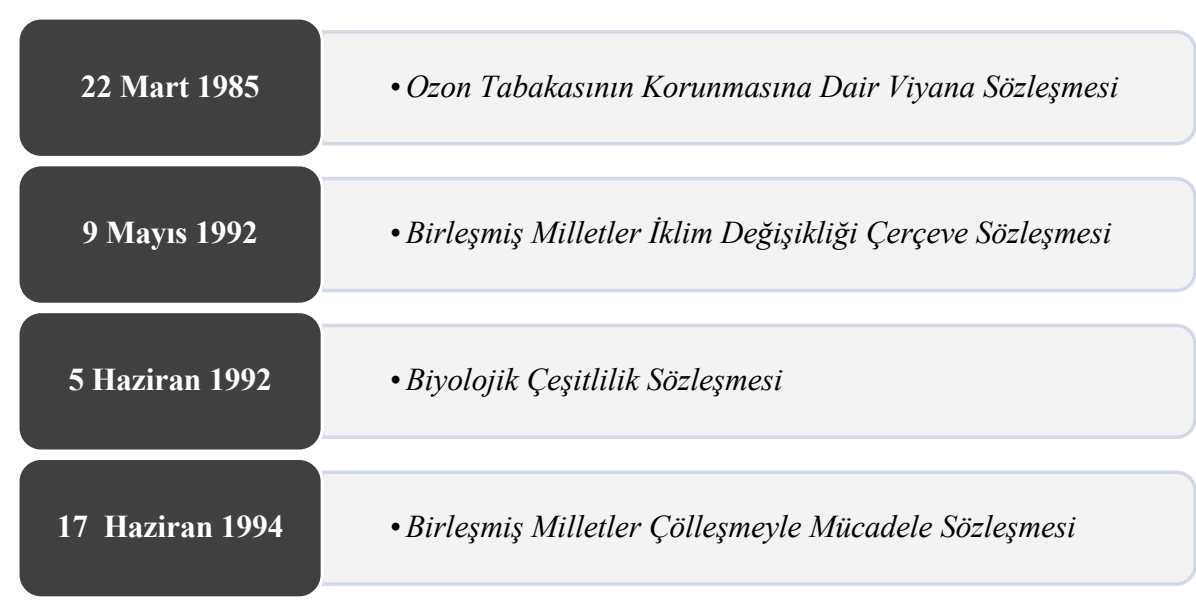

Şekil 6. Fransa’nın Taraf Olduğu Bazı Uluslararası Çevre Anlaşmaları. (Legifrance, 2020)'den faydalanılarak hazırlanmıştır.

Temel anayasal bir belge özelliğinde olan Çevre Şartı, önce Ulusal Meclis daha sonra Senato tarafından onay almış olup 2005 yılında yapılan anayasal değişiklikler esnasında Fransız Anayasası'na dahil edilmiştir (Güneş ve Münster, 2011, s. 271). Bir giriş kısmı ve on maddeden oluşan şartın asıl amacı, farklı hukuki metinlerde bulunan, çevrenin korunması doğrultusunda belirlenmiş olan ilkeleri anayasal bir düzlemde bir araya getirmek ve korumaktır (Güneş ve Münster, 2011, s. 272; Vie Publique, 2020).

Çevre Şartı, daha önceki yıllarda kabul ettiği, çevre hukuku konusundaki uluslararası düzenlemeleri ve iç hukuka aktardığ $\mathrm{AB}$ normları dolayısıyla önemlidir (Prieur, 2004 aktaran Yurtcanlı, 2012, s. 314). Şartın giriş kısmı incelendiğinde, çevrenin korunması konusunda çevre özgün bir değer olarak alınmadığı, insan-merkezci yaklaşımdan hala tam anlamıyla uzaklaşılamadığı görülmektedir (Yurtcanlı, 2012, s. 315).

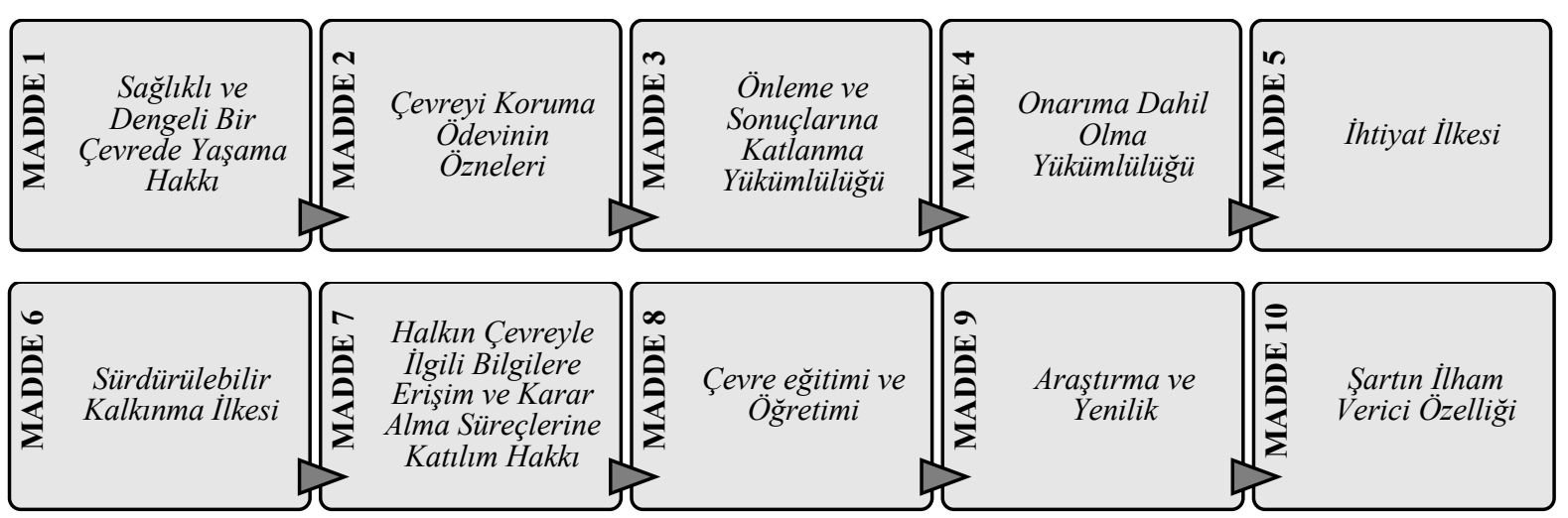

Şekil 7. Fransız Çevre Şartı Maddelerinin Temel İçerikleri. (Conseil Constitutionnel, 2020) adresinden faydalanılarak hazırlanmıştır.

Fransız Çevre Şartı'nın Şekil 7'de kısaca verilen maddeleri incelendiğinde; birinci maddede çevre hakkının, anayasal bir temel hak özelliğine kavuştuğu görülmektedir. Bu maddeyle birlikte sağlıklı ve dengeli bir çevrede yaşama hakkı resmi olarak koruma altına alınmıştır ve diğer maddelerin de temelini oluşturmaktadır. İkinci maddede ise çevrenin korunması konusunda yükümlülügün sadece devlete değil tüm insanlığa ait olduğu vurgulanmıştır. Bununla birlikte, devlete ve bireye karşılıklı sorumluluk yüklenerek yapılan çalışmaların etkililiği arttırılmıştır. Üçüncü maddede, insanlar çevresel zararları önlemekle, önlenemeyen durumlarda ise sonuçların hafifletilmesi konusunda sorumlu tutulmuştur bunun yanında dördüncü maddede ise her insanın 
sebep olduğu çevresel sorunun çözümüne katkı sağlamakla görevli olduğu belirtilmiştir. Şartın beşinci maddesinde, çevre hukukunun temel ilkelerinden biri olan ihtiyat ilkesi düzenlenmiştir. Güneş ve Münster, (2011, s. 267) yaptıkları çalışmada ihtiyat ilkesinden, 1970'li yıllarda Almanya'da uygulamaya aktarıldığı ve herhangi bir faaliyetin çevresel sorunlar ortaya çıkaracağı konusunda güçlü bir şüphe olduğu takdirde bilimsel bir kanıt beklemeden önleyici eylemlerin oluşturulması anlamına geldiği şeklinde bahsetmişlerdir. Altıncı maddede, şartın giriş kısmında da değinilen sürdürülebilir kalkınma ilkesine yer verilmiştir. Bununla birlikte, sürdürülebilir kalkınmanın sağlanabilmesi için ekonomik kalkınma ve sosyal gelişmenin korunması ve çevreyle uzlaştırılması gerekliliği vurgulanmıştır. Metnin yedinci maddesinde ise çevresel bilgiye halkın erişimi ve çevresel karar alma sürecine halkın katılımı konusu değerlendirilmiştir. Sekiz ve dokuzuncu maddelerde eğitim, araştırma ve yeniliklerin çevrenin korunmasına katkı sağlamasının gerekliliğine yer verilmiştir. Son olarak onuncu maddede ise şartın Fransa'nın $A B$ ve uluslararası ölçekteki çalışmalarına ilham vereceği hususuyla çalışma sonlandırılmıştır (Conseil Constitutionnel, 2020).

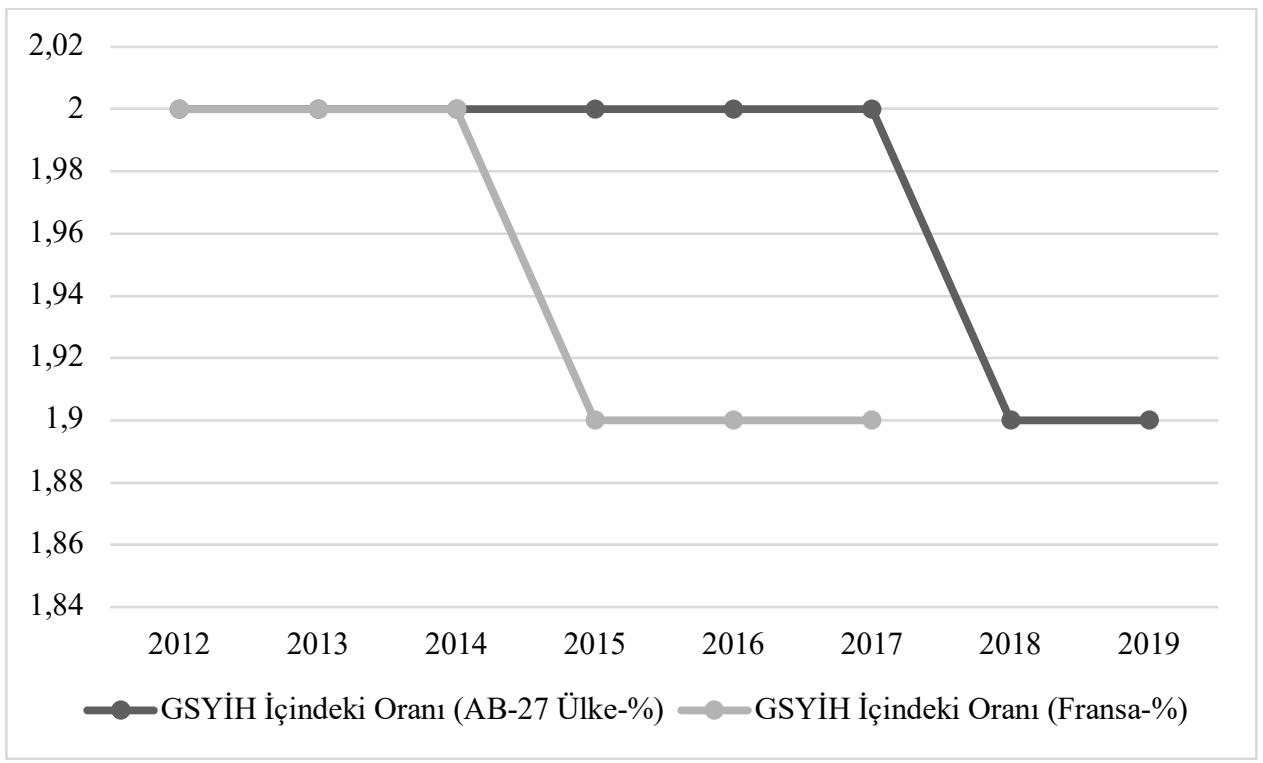

Grafik 2. AB-27 Ülke ve Fransa’nın Çevre Koruma Harcamalarının GSYİH İçindeki Payı.

(Eurostat, 2021b) adresinden alınan veriler doğrultusunda oluşturulmuştur.

Çevre koruma alanında Fransa'nın yaptığı çalışmalar uluslararası alanda yapılan çalışmalarla karşılaştırıldığında görülmektedir ki Fransa bu konuda avantajı bir durumdadır. Hatta Fransız Çevre Şartı gibi bir uygulama metnine sahip olması uluslararası alanda örnek olarak gösterilebilecek öncü bir düzenleme olarak kabul edilebilir. Fransa’nın bu alandaki yetkinliğini destekleyecek olan bir diğer veri ise çevre koruma harcamalarıdır. Grafik 2'de yer verildiği gibi Fransa'nın çevresel koruma harcamalarının GSYİH'ye oranı AB'ye üye 27 ülkenin ortalamasıyla karşılaştırıldığında arasında fark görünmemektedir. 2014 yılına kadar eşit giden bu oran 2015 yılında Fransa'nın 0,1'lik küçük bir azalma yaşamasıyla değişmiştir. Ancak; sonuç olarak, Fransa'nın çevre koruma ve çevre hakkı konusundaki genel görünümü olumlu izlenim bırakmaktadır.

\section{Çevre Hakkı Kavramının Türkiye Özelinde Analizi}

Türkiye'de çevre hakkı konusundaki çalışmalar ağırlıklı olarak 1970'li yıllardan sonra başlamıştır. Yaşanılan bu gelişmenin 1970'li yıllara denk gelmesinin başlıca sebebi BM İnsan Çevresi Bildirisi'dir. Bu bildiriyle başlayan süreçte Türkiye'nin taraf olduğu birçok uluslararası belge imzalanmıştır. Tablo 3'te örnekleri verildiği üzere Ozon Tabakasının Korunmasına Dair Viyana Sözleşmesi, gibi Türkiye’nin çevresel alanda taraf olduğu 
başlıca 30 uluslararası anlaşma mevcuttur (T.C. Dışişleri Bakanlığı, 2020b). Anlaşmaların yanı sıra birçok konferansa katılım sağlanmıştır. Çevre sorunlarını önleme, çevreyi koruma ve çevre hakkı konusunda Türkiye'nin katıldığı konferanslara Sekizinci Taraflar Konferansı (2007) ve Paris'te gerçekleştirilen İklim Konferansı (2015) örnek olarak gösterilebilir (T.C. Çevre ve Şehircilik Bakanlığı, 2016, s. 52-238).

Tablo 3

Türkiye’nin Taraf Olduğu Bazı Uluslararası Çevre Anlaşmaları

\begin{tabular}{c|c|c|c|c|c}
\hline BELGE ADI & İÇERIK & YERİ & $\begin{array}{c}\text { IMZA } \\
\text { TARİ } \\
\text { İ }\end{array}$ & $\begin{array}{c}\text { YÜRÜRLÜ } \\
\text { K TARİHİ }\end{array}$ & $\begin{array}{c}\text { TARAF } \\
\text { OLMA } \\
\text { TARİH }\end{array}$ \\
\hline $\begin{array}{c}\text { Ozon Tabakasının } \\
\text { Korunmasına Dair Viyana } \\
\text { Sözleşmesi }\end{array}$ & $\begin{array}{c}\text { Ozon tabakasını incelten } \\
\text { maddelerin azaltılmasına } \\
\text { ilişkin yasal bağlayıcllı̆ı } \\
\text { olmayan çerçeve sözleşme. }\end{array}$ & Viyana & 1985 & 1988 & 1991 \\
\hline $\begin{array}{c}\text { Ozon Tabakasını İncelten } \\
\text { Maddelere Dair Montreal } \\
\text { Protokolï }\end{array}$ & $\begin{array}{c}\text { Ozon tabakasını incelten } \\
\text { maddelerin kontrol altına } \\
\text { alınmasına yönelik protokol. }\end{array}$ & $\begin{array}{c}\text { Montre } \\
\text { al }\end{array}$ & 1987 & 1989 & 1991 \\
\hline $\begin{array}{c}\text { BM İklim Değişikliği } \\
\text { Çerçeve Sözleşmesi }\end{array}$ & $\begin{array}{c}\text { Sera gazı oranını iklim } \\
\text { sistemini etkilemeyecek } \\
\text { düzeyde tutmak. }\end{array}$ & $\begin{array}{c}\text { Rio de } \\
\text { Janeiro }\end{array}$ & 1992 & 1994 & 2004 \\
\hline $\begin{array}{c}\text { Karadeniz'in Kirlenmeye } \\
\text { Karşı Korunması } \\
\text { Sözleşmesi }\end{array}$ & $\begin{array}{c}\text { Karadeniz'deki kirliliği } \\
\text { ölemek için yasal çerçeve } \\
\text { oluşturmak. }\end{array}$ & Bükreş & 1992 & 1994 & 1994 \\
\hline
\end{tabular}

Kaynak: (T.C. Dışişleri Bakanlığı, 2020b), (Black Sea Comission, 2020), (T.C. Çevre ve Şehircilik Bakanlığı, 2020a), (T.C. Çevre ve Şehircilik Bakanlığı, 2020b) ve (T.C. Çevre ve Şehircilik Bakanlı̆̆ı, 2020c)'den faydalanılarak oluşturulmuştur.

Uluslararası belge ve anlaşmaların onaylanması uygulama açısından yeterli değildir bunun yanında iç hukuka aktarılması da gerekmektedir. Kaya (2011, s. 447), çalışmasında, Türkiye'nin mevzuat açısından bu konuda yetersiz kaldığını söyler. Bilindiği üzere, uluslararası anlaşmaların iç hukuka aktarılması hususunda 1982 Anayasası'nın 90. maddesine "Usulüne göre yürürlüğe konulmuş Milletlerarası andlaşmalar kanun hükmündedir.” ifadesi eklenmiştir (T.C. Anayasası, 1982). Bu durum teorik olarak doğru fakat pratikte, özellikle anlaşmaların uygulama safhasında bir uygulama mevzuatının zorunluluğu açıktır (Kaynak, 1998 aktaran Kaya, 2011, s. 447). Tablo 4’te yer aldığı üzere Türkiye, çevre koruması hakkında taraf olduğu anlaşmaların uygulanmasına yönelik yasal düzenlemeler oluşturma konusunda yavaş kaldığı ve yeterince hassas davranmadığı görülmektedir. Çevre hakkını doğrudan desteklemese de bu tarz çalışmaların varlığı, dolaylı olarak çevre hakkı uygulamasında da etki sağladığı için önemlidir. Ulusal mevzuatın yeterli olmamasının yanı sıra çevrenin korunmasına yönelik önemli adımlar da atmaktadır. Özellikle son on yıldır konferanslara aktif olarak katılan ve sorumluluk almakta istekli olan ülkelerden biridir. Örneğin, 2020 senesinde gerçekleştirilmesi hedeflenen 26. İklim Değiş̧ikliği Taraflar Konferansı'nın ev sahipliğini üstlenme konusundaki talebini açıkça dile getirmiştir (T.C. Çevre ve Şehircilik Bakanlığı, 2016, s. 57). 
Tablo 4

Türkiye'nin Taraf Olduğu Bazı Çevre Anlaşmaları ve Ulusal Uygulama Mevzuatı

\begin{tabular}{|c|c|c|c|}
\hline ÇOK TARAFLI ÇEVRE ANLAŞMASI & $\begin{array}{l}\text { ONAY } \\
\text { TARIHII }\end{array}$ & ULUSAL MEVZUAT & $\begin{array}{l}\text { YÜRÜRLÜK } \\
\text { TARIHII }\end{array}$ \\
\hline \multirow{3}{*}{ Biyolojik Çeşitlilik Sözleşmesi (1992) } & \multirow{3}{*}{1997} & Orman Kanunu & $1956 / 2004$ \\
\hline & & Hayvanları Koruma Kanunu ve Uygulama Yönetmeliği & 2004-2006 \\
\hline & & $\begin{array}{c}\text { Yaban Hayatı Koruma ve Yaban Hayatı Geliştirme } \\
\text { Sahaları Yönetmeliği }\end{array}$ & 2004 \\
\hline \multirow[b]{2}{*}{ Cartagena Biogüvenlik Protokolü (2000) } & \multirow[b]{2}{*}{2003} & Biyogüvenlik Kanunu & 2010 \\
\hline & & $\begin{array}{c}\text { Gıda ve Yem Amaçlı Genetik Yapısı Değiştirilmiş } \\
\text { Organizmalar ve Ürünlerin İthalatı, İslenmesi, İhracatı, } \\
\text { Kontrol ve Denetimine Dair Yönetmelik / Genetik Yapısı } \\
\text { Değiştirilmiş Organizmalar ve Ürünlerine Dair } \\
\text { Yönetmelik } \\
\end{array}$ & $2009-2010$ \\
\hline $\begin{array}{c}\text { Ozon Tabakasının Korunmasına Dair } \\
\text { Viyana Sözleşmesi (1985) }\end{array}$ & 1990 & $\begin{array}{c}\text { Ozon Tabakasını İncelten Maddelerin Azaltılmasına } \\
\text { Dair Yönetmelik }\end{array}$ & $1999 / 2008$ \\
\hline $\begin{array}{c}\text { Ozon Tabakasını İncelten Maddelere Dair } \\
\text { Montreal Protokolï (1987) }\end{array}$ & 1990 & $\begin{array}{c}\text { Ozon Tabakasını İncelten Maddelerin Azaltılmasına } \\
\text { Dair Yönetmelik }\end{array}$ & $1999 / 2008$ \\
\hline \multirow{2}{*}{$\begin{array}{c}\text { BM İklim Değişikliği Çerçeve Sözleşmesi } \\
(1992)\end{array}$} & \multirow[b]{2}{*}{2003} & Hava Kalitesinin Korunması Yönetmeliği & $1986 / 2004$ \\
\hline & & $\begin{array}{c}\text { Endüstri Tesislerinden Kaynaklanan Hava Kirliliğinin } \\
\text { Kontrolü Yönetmeliği } \\
\end{array}$ & $2004 / 2006$ \\
\hline \multirow{2}{*}{ Kyoto Protokolï (1997) } & \multirow{2}{*}{2009} & Yenilenebilir Enerji Kanunu & 2007 \\
\hline & & Enerji Verimliliği Kanunu & 2007 \\
\hline \multirow{3}{*}{$\begin{array}{l}\text { MARPOL Convention (1973) (Denizlerin } \\
\text { Gemiler Tarafından Kirletilmesinin } \\
\text { Önlenmesine İlişkin Uluslararası Sözleşme) }\end{array}$} & \multirow{3}{*}{1990} & $\begin{array}{c}\text { Deniz Çevresinin Petrol ve Diğer Zararlı Maddelerle } \\
\text { Kirletilmesinde Acil Durumlarda Müdahale ve Zararın } \\
\text { Tazmini Esaslarına Dair Kanun ve Uygulama } \\
\text { Yönetmeliği }\end{array}$ & 2005-2006 \\
\hline & & $\begin{array}{c}\text { Antarktika'da Çevre Koruma Protokolünün } \\
\text { Uygulanmasına Dair Yönetmelik }\end{array}$ & 2020 \\
\hline & & $\begin{array}{c}\text { Gemilerden Atık Alınması ve Atıkların Kontrolü } \\
\text { Yönetmeliği }\end{array}$ & 2004 \\
\hline $\begin{array}{c}\text { Ramsar Sözleşmesi (1971) (Özellikle Su } \\
\text { Kuşları Yaşama Alanı Olarak Uluslararası } \\
\text { Öneme Sahip Sulak Alanlar Hakkında } \\
\text { Sözleşme) }\end{array}$ & 1994 & Sulak Alanların Korunması Yönetmeliği & $2002 / 2005$ \\
\hline $\begin{array}{l}\text { CITES (1973) (Nesli Tehlikede Olan Hayvan } \\
\text { ve Bitki Türlerinin Uluslararası Ticaretinin } \\
\text { Düzenlenmesine İlişkin Sözleşme) }\end{array}$ & 1996 & $\begin{array}{c}\text { Nesli Tehlike Altında Olan Yabani Hayvan ve Bitki } \\
\text { Türlerinin Uluslararası Ticaretine İlişkin Sözleşmenin } \\
\text { Uygulanmasına Dair Yönetmelik (CITES Uygulama } \\
\text { Yönetmeliği) } \\
\end{array}$ & $2001 / 2004$ \\
\hline \multirow{5}{*}{$\begin{array}{l}\text { Bükreş Sözleşmesi (1992) (Karadeniz’in } \\
\text { Kirliliğe Karşı Korunması Sözleşmesi) }\end{array}$} & \multirow{5}{*}{1994} & Sular Hakkında Kanun & 1926 \\
\hline & & Kıyı Kanunu ve Uygulanmasına Dair Yönetmelik & 1990-1992 \\
\hline & & Su Kirliliği Kontrolü Yönetmeliği & $1988 / 2004$ \\
\hline & & $\begin{array}{l}\text { Tehlikeli Maddelerin Su Çevresinde Neden Olduğu } \\
\text { Kirliliğin Kontrolüne İlişkin Yönetmelik }\end{array}$ & 2005 \\
\hline & & $\begin{array}{c}\text { Tarımsal Kaynaklı Nitrat Kirliliğine Karşı Suların } \\
\text { Korunması Yönetmeliği }\end{array}$ & 2004 \\
\hline \multirow{5}{*}{$\begin{array}{l}\text { Barselona Sözleşmesi (1976) (Akdeniz’in } \\
\text { Kirlenmeye Karşı Korunması Sözleşmesi) }\end{array}$} & \multirow{5}{*}{1981} & Sular Hakkında Kanun & 1926 \\
\hline & & Kıyı Kanunu ve Uygulanmasına Dair Yönetmelik & 1990-1992 \\
\hline & & Su Kirliliği Kontrolü Yönetmeliği & $1988 / 2004$ \\
\hline & & $\begin{array}{l}\text { Tehlikeli Maddelerin Su Çevresinde Neden Olduğu } \\
\text { Kirliliğin Kontrolüne İlişkin Yönetmelik } \\
\end{array}$ & 2005 \\
\hline & & $\begin{array}{c}\text { Tarımsal Kaynaklı Nitrat Kirliliğine Karşı Suların } \\
\text { Korunması Yönetmeliği }\end{array}$ & 2004 \\
\hline \multirow{5}{*}{$\begin{array}{l}\text { Basel Sözleşmesi (1989) (Tehlikeli Atıkların } \\
\text { Sınırötesi Taşınımının ve Bertarafının } \\
\text { Kontrolüne İlişkin Sözleşme) }\end{array}$} & \multirow{5}{*}{1994} & Katı Atıkların Kontrolü Yönetmeliği & 1991 \\
\hline & & Tehlikeli Atıkların Kontrolü Yönetmeliği & $1995 / 2005$ \\
\hline & & Tıbbi Atıkların Kontrolü Yönetmeliği & $1993 / 2005$ \\
\hline & & Atık Yönetiminin Genel Esaslarına İlişkin Yönetmelik & 2008 \\
\hline & & Atıkların Düzenli Depolanmasına Dair Yönetmelik & 2010 \\
\hline $\begin{array}{l}\text { Madrid Protokolï (1991) (Antarktika } \\
\text { Sözleşmesi Çevre Koruma Protokolü) }\end{array}$ & 1998 & $\begin{array}{c}\text { Antarktika'da Çevre Koruma Protokolünün } \\
\text { Uygulanmasına Dair Yönetmelik }\end{array}$ & 2017 \\
\hline $\begin{array}{c}\text { ICCAT (1966) (Atlantik Ton Balıklarının } \\
\text { Korunmasına İlişsin } \\
\text { Uluslararası Sözleşme) } \\
\end{array}$ & 1969 & $\begin{array}{c}2017 \text { Yılında Mavi Yüzgeçli Orkinos Avcılığı Yapacak } \\
\text { Gemilerin Belirlenmesi ve Bu Gemilere Yapılacak Kota } \\
\text { Tahsisine İlişkin Tebliğ }\end{array}$ & 2017 \\
\hline
\end{tabular}


Çevreye ilişkin uluslararası çalışmaların devletlerin iç hukukuna ve politikalarına yansımaları, farklı şekillerde görülmektedir. Çevre hakkının Türkiye'de temel norm olarak doğrudan düzenlenmesi ilk kez 1982 Anayasası'nın 56. maddesiyle gerçekleşmiştir. Adı geçen maddede çevre hakkı "Herkes, sağlıklı ve dengeli bir çevrede yaşama hakkına sahiptir. Çevreyi geliştirmek, çevre sağlığını korumak ve çevre kirlenmesini önlemek Devletin ve vatandaşların ödevidir.” şeklinde bahsedilerek devlete ve vatandaşlara sorumluluk yüklenmiştir. Bunun haricinde 1982 Anayasası'nın 43, 44 ve 45. maddeleri gibi doğrudan olmasa da çevre hakkıyla bağlantılı başka hükümler de bulunmaktadır (T.C. Anayasası, 1982). Daha önceki 1924 Anayasası ve 1961 Anayasası'nda çevre hakkı düzenlemesine yönelik doğrudan bir madde bulunmamaktadır (T.C. Anayasası, 1924; T.C. Anayasas1, 1961).

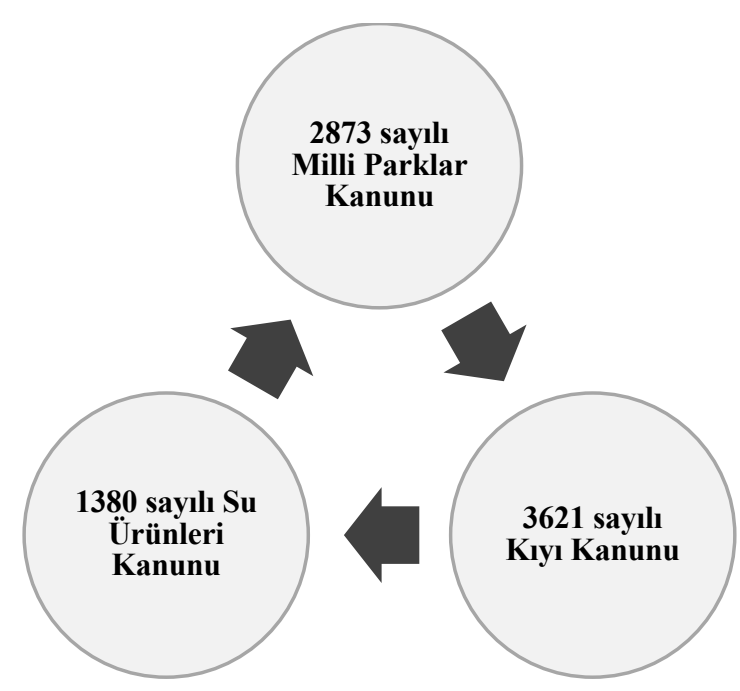

Şekil 8. Çevre Hakkını Destekleyici Mahiyette Kanun Örnekleri. (Milli Parklar Kanunu, 1983),

(Kıyı Kanunu, 1990) ve (Su Ürünleri Kanunu, 1971)'den faydalanılarak hazırlanmıştır.

Çevre hakkını anayasa dışında destekleyen önemli belgelerden biri de kanunlardır. Bu konudaki metinlerden en önemlisi 2872 sayılı Çevre Kanunu'dur. Kanunun amacı, birinci maddede "Bütün canlıların ortak varlığı olan çevrenin, sürdürülebilir çevre ve sürdürülebilir kalkınma ilkeleri doğrultusunda korunmasını sağlamaktır.” şeklinde açıklanmıştır (Çevre Kanunu, 1983). Bunun dışında Şekil 8'de yer verilen ve çevre hakkıyla doğrudan ilişkili olmasa da destekleyici mahiyette bulunan birçok kanun mevcuttur. Bunlara 2873 sayılı Milli Parklar Kanunu (11.08.1983), 3621 sayılı Kıyı Kanunu (17.04.1990) ve 1380 sayılı Su Ürünleri Kanunu (04.04.1971) örnek olarak gösterilebilir (Milli Parklar Kanunu, 1983; Kıyı Kanunu, 1990; Su Ürünleri Kanunu, 1971). Yukarıda bahsedilenler dışında, çevre hakkını desteklemek amacıyla Çevre ve Şehircilik Bakanlığı bünyesindeki başkanlıkların yayımladığı ve resmi internet sitesinde yer alan 53 yönetmelik, 27 tebliğ ve 52 genelge bulunmaktadır (csb.gov.tr/, 2020). 
Tablo 5

AB-27 Ülke ve Türkiye'nin Çevre Koruma Harcamalarının GSYİH İçindeki Payı

\begin{tabular}{|c|c|c|c|c|c|c|c|c|}
\hline & 2012 & 2013 & 2014 & 2015 & 2016 & 2017 & 2018 & 2019 \\
\hline $\begin{array}{r}\text { TOPLAM ÇEVRESEL HARCAMALAR } \\
\text { (TÜRKİYE-Milyar } \mathbf{5})\end{array}$ & 17,6 & 19,3 & 20,7 & 25,9 & 31,8 & 34,4 & 38,2 & 38,4 \\
\hline GSYİH İÇINDEKİ ORANI (TÜRKIYYE) & $\% 1,2$ & $\% 1,2$ & $\% 1,2$ & $\% 1,3$ & $\% 1,2$ & $\% 1,11$ & $\% 1$ & $\% 0,9$ \\
\hline $\begin{array}{r}\text { TOPLAM ÇEVRESEL HARCAMALAR } \\
(\text { AB-27 ÜLKE-Milyon } €)\end{array}$ & 115,5 & 115,4 & 117,6 & 120,3 & 122,5 & 127,5 & 128,9 & 133,6 \\
\hline GSYİH İÇİNDEKİ ORANI (AB-27 ÜLKE) & $\% 2$ & $\% 2$ & $\% 2$ & $\% 2$ & $\% 2$ & $\% 2$ & $\% 1,9$ & $\% 1,9$ \\
\hline
\end{tabular}

Kaynak: (TÜİK, 2020), (Eurostat, 2021a) ve (Eurostat, 2021b) adreslerinden alınan veriler doğrultusunda oluşturulmuştur.

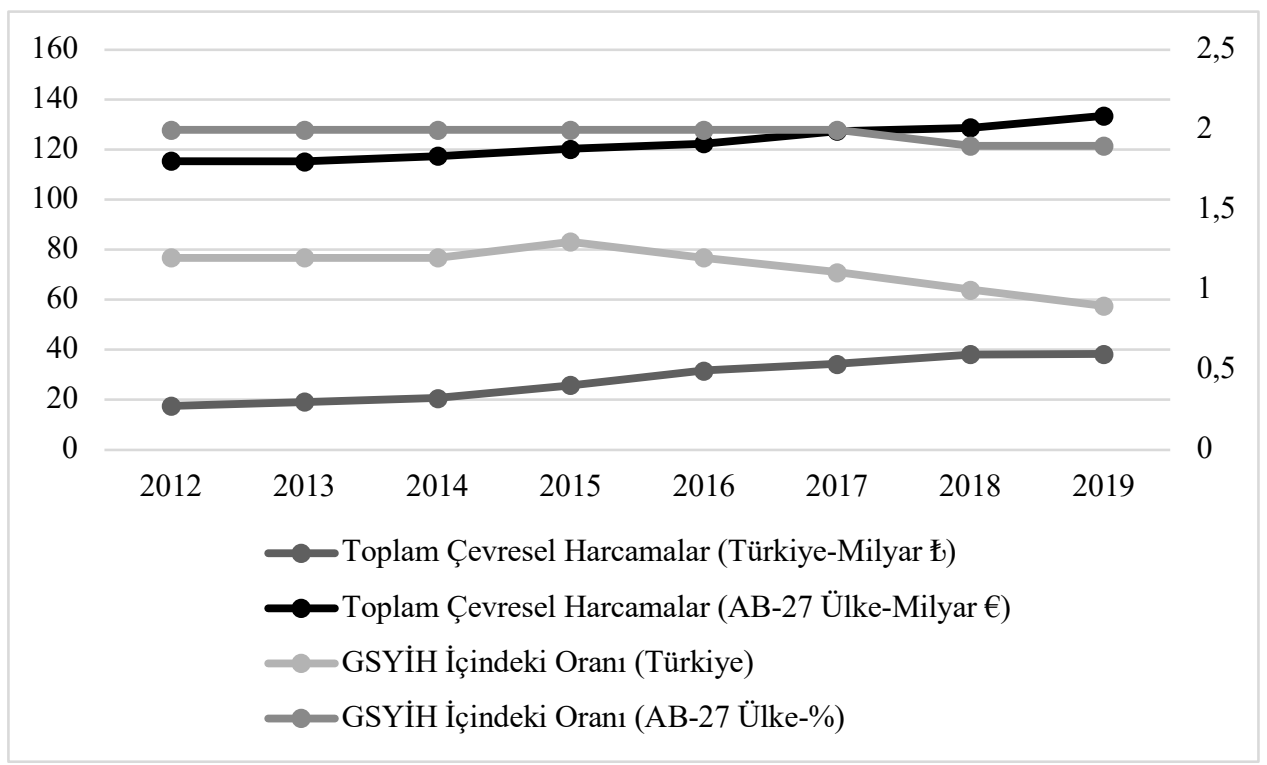

Grafik 3. AB-27 Ülke ve Türkiye’nin Çevre Koruma Harcamalarının GSYİH İçindeki Payı. (TÜİK, 2020) ve (Eurostat, 2021a) ve (Eurostat, 2021b) adreslerinden alınan veriler doğrultusunda oluşturulmuştur.

Dünyada yapılan çalışmalarla Türkiye özelinde yapılan çalışmaların karşılaştırılması göstermektedir ki Türkiye'nin bu konuda çabaladığı ve gerçekleştirdiği önemli adımlar olsa da daha gidecek yolu bulunmaktadır. Bu bilgiyi ekonomik bağlamda destekleyen veri ise ülke genelinde yapılan çevresel harcamalardır. Ülkelerin bu konudaki durumlarını açıklamak ve karşılaştırmak için T.C. Çevre ve Şehircilik Bakanlığı tarafından hazırlanan çevresel göstergeler (T.C. Çevre ve Şehircilik Bakanlığı, 2020, s. 2-5), OECD tarafından hazırlanan çevresel performans verileri ve su kalitesi parametreleri (OECD, 2008, s. 73 ve 244) gibi başka ölçütlerde bulunmaktadır. Ancak nicel bir veri ve tüm ülkeleri kapsayan bir kıstas olması sebebiyle, bu çalışmada çevresel performansın değerlendirilmesinde ilgili ülkelerin çevre koruma harcamalarına odaklanılmıştır. Çevre koruma harcamaları, Çevre ve Şehircilik Bakanlığı'nın yaptığı tanımlamaya göre, çevresel bozulmalarla ilgili olan ve gerek önleyici gerekse iyileştirici nitelikteki eylem ve faaliyetlerde kullanılmak üzere ayrılan bütçedir (T.C. Çevre ve Şehircilik Bakanlığı, 2020d). AB üyesi olan 27 ülkenin ve Türkiye'nin çevre korumaya ilişkin 20122019 yıllarına ait verileri Avrupa İstatistik Ofisi ve Türkiye İstatistik Kurumu’ndan (TÜİK) alınmıştır. Elde edilen veriler doğrultusunda oluşturulan Tablo 5 ve Grafik 3 incelendiğinde, Türkiye'deki çevresel konularda 
yapılan harcamaların düzenli bir şekilde artış gösterdiği, özellikle 2014 yılı ile göreceli olarak bir sıçramanın yaşandığı görülmektedir. Ancak diğer yandan, Türkiye'de yapılan harcamaların GSYİH içindeki oranı göz önünde tutulduğunda 2015 yılı ile bu yıla kadar süregelen düzenli artışın yerini azalmaya bıraktığı görülür. Ancak; bu durumun tek başına olumsuz bir gelişme olarak yorumlanamayacağı açı olsa da her geçen yıl çevresel koruma için ayrılan miktarın artmasına rağmen GSYİH içinde oranın düşme eğilimi göstermesi bir olumsuzluk göstergesidir. Türkiye’nin toplam çevresel harcamalarının GSYİH içindeki oranıyla AB ülkelerinin ortalamasına ait oranlar karşılaştırıldığında ekonomik bağlamda da çevre koruma ve dolayısıyla çevre hakkı konusunda dezavantajlı bir durumda kalmaktadır.

\section{Değerlendirme}

Çalışmanın daha önceki bölümlerinde elde edilen bulguların Tablo 6'yla genel bir değerlendirmesi yapılacak olursa, öncelikle uluslararası alanda çevrenin doğrudan bir hak olarak yer alması BM İnsan Çevresi Bildirisi'yle gerçekleşmiştir. Temel haklara erişmede bir ön koşul olarak görülen çevre hakkı Dayanışma Haklarına İlişkin Uluslararası Üçüncü Pakt Ön Tasarısı’yla dayanışma hakları arasındaki yerini almıştır. Temelinde insan kaynaklı olgular ve çevrecilik düşüncesi yatan kavram çok ögeli olması sebebiyle kuşaklar arası bir niteliğe bürünerek gelecek nesilleri de kapsamaktadır. Belirli zamansal ve mekânsal kalıplara sığdırılamayan çevre hakkı sürdürülebilir kalkınma gibi çeşitli alanlara entegre edilerek etki alanının genişletilmesi sağlanmıştır.

Tablo 6

Elde Edilen Bulgular ve Değerlendirmesi

\begin{tabular}{|c|c|c|}
\hline \multicolumn{2}{|r|}{ BULGU KAYNAĞI } & İÇERİK \\
\hline 1 & BM İnsan Çevresi Bildirisi (1972) & Uluslararası alanda cevrenin bir hak olarak yer alması. \\
\hline 2 & Çolakoğlu (2010, s. 154) & $\begin{array}{l}\text { Çevre hakkının temel insan haklarına erişmede önemli bir ön } \\
\text { koşul olması. }\end{array}$ \\
\hline 3 & $\begin{array}{l}\text { Dayanışma Haklarına İlişkin Uluslararası } \\
\text { Üçüncü Pakt Ön Tasarısı }\end{array}$ & Çevre hakkının dayanıșma hakkı olarak kabul edilmesi. \\
\hline 4 & Kara $(2012$, s. 91-92) & $\begin{array}{c}\text { Çevre hakkının oluşmasında küresel ısınma gibi insan } \\
\text { kaynaklı sebeplerin bulunması. }\end{array}$ \\
\hline 5 & Güveyi $(2018$, s. 635) & Çevre hakkının temelinde çevrecilik düșüncesi yatması. \\
\hline 6 & Özdek (1993, s. 91-92) & Çevre hakkı çok ögeli ve gelecek nesilleri de kapsaması. \\
\hline 7 & Brundtland Raporu (1987) & Çevre hakkının $\frac{\text { sürdürülebilir kalkınma }}{\text { değerlendirilmesi. }}$ \\
\hline 8 & Brundtland Raporu (1987) & $\begin{array}{c}\text { Çevre hakkı gelecek } \text { kușaklarında hakkı olarak kabul } \\
\text { edilmesi. }\end{array}$ \\
\hline 9 & Özdek (1993, s. 91-92) & Çevre hakkının mekânsal ve zamansal ögelerinin olmaması. \\
\hline 10 & $\operatorname{Kaypak}(2017$, s. 9) & Çevre hakkının belirli bir sınırı ve etki alanının olmaması. \\
\hline 11 & $\begin{array}{l}\text { Abdulhekimoğulları, Sezer ve Akpınar } \\
(2011, \text { s. 65) }\end{array}$ & Çevre hakkının nesilleri arası etkileşimi içermesi. \\
\hline 12 & Keleş $(1994$, s. 276) & Çevre hakkının 1970'li yıllarda çăğdaș anayasalara girmesi. \\
\hline 13 & San Salvador Protokolï (1988) & Sağlıklı bir çevrede yaşamanın bir $\underline{\mathbf{h a k}}$ olarak belirtilmesi. \\
\hline 14 & $\begin{array}{l}\text { Afrika İnsan ve Halkların Hakları Şartı } \\
\text { (1981) }\end{array}$ & $\begin{array}{l}\text { Çevre hakkının öznesi olarak halkların kabul edilmesi. } \\
\text { Çevre hakkı konusunda ilk bağlayıcı belge olması. }\end{array}$ \\
\hline 15 & Doğa Şartı (1982) & Prosedürel haklar ve çevre hakkı ilişkisine dair ilk belge. \\
\hline 16 & Aarhus (1998) & $\begin{array}{c}\text { Sağliklı ve dengeli bir çevrede yaşamanın hak olarak yer } \\
\text { alması. }\end{array}$ \\
\hline 17 & Fransız Çevre Şartı (2005) & Cevre ve çevre hakkı özelinde kapsamlı bir belge olması. \\
\hline 18 & 1982 Anayasasi & 56. maddede çevre hakkı doğrudan düzenlenmiştir. \\
\hline
\end{tabular}

Çevre hakkı üzerine yapılan çalışmaların daha eskiye dayanmasına rağmen kavramın görünür hale gelmesi ve anayasalara girmeye başlaması 1970’li yılları bulmuştur. Türkiye'de ise 1982 yılında anayasada doğrudan yer almıştır. Uluslararası alanda düzenlenen konferanslar dışında çevre hakkıyla doğrudan ilişkili San Salvador 
Protokolü, Afrika İnsan ve Halkların Hakları Şartı, Doğa Şartı ve Aarhus Sözleşmesi gibi metinler bulunmaktadır. Çevre hakkını çeşitli açılardan ele alan bu metinler kavramın gelişmesinde ve güçlenmesinde önemli rol oynamıştır. Çalışmada örnek ülke olarak seçilen Fransa'da birçok ulusal ve uluslararası çalışmaya imza atmıştır fakat; araştırmaya dahil edilmesinin asıl sebebi 1 Mart 2005 tarihinde anayasasına eklediği Çevre Şartı'dır. Çevre Şartı'nı önemli kılan husus ise diğer ülkelerin anayasalarında doğrudan tek madde de yer verdiği çevre hakkını 10 maddelik ayrı bir metin olarak ele almasıdır. Belgenin asıl amacı ise farklı hukuki metinlerde bulunan, çevrenin korunması doğrultusunda belirlenmiş olan ilkeleri anayasal bir düzlemde bir araya getirmek ve korumak olarak açıklanabilir.

Türkiye özelinde bakıldığında gerek doğrudan gerekse dolaylı olarak çeşitli çalışmalar bulunmaktadır. Bunun temelinde ise 1982 Anayasası'nın 56. maddesi yer almaktadır. Gerçekleştirilen uygulamalar yukarıda bahsedilenlerle sınırlı olmamakla birlikte yapılan tarama neticesinde önemli görülenler araştırmaya dahil edilmiştir. Ele alınan çalışmalar doğrultusunda genel bir değerlendirme yapılacak olursa; uluslararası alanda gerçekleştirilen konferanslar, anlaşmalar ve diğer birçok metin çevre konusuna olumlu katkılar sağlamakla birlikte tam olarak istenilen seviyeye ulaşamamıştır. Fransa özelinde değerlendirildiğinde ise önemli çalışmaları bulunmakla birlikte en çok göze çarpan konu Çevre Şartı olmuştur. Çevre hakkı konusunda henüz dünya bile çok yol kat edememişken, Türkiye'nin şimdiye kadar gösterdiği çabaların ve geçmişte hayata geçirdiği çalışmaların, olumlu sonuçlarının önümüzdeki yıllarda kendisini göstereceği düşünülmektedir.

\section{Sonuç ve Öneriler}

Çevresel sorunların artan bir ivmeyle varlığını sürdürmesi ve etki alanını genişletmesi ülkelerin tek başına mücadele edemeyeceği bir noktaya gelmesine sebep olmuştur. Bunun sonucunda çevre ve dayanışma temelli küresel birçok konferans düzenlenmiş, anlaşma imzalanmış ve taraf ülkelerden de bunları ulusal düzeyde uygulaması beklenmiştir. Çevre hakkının uluslararası alanda gündeme gelmesi yukarıda da bahsedilen genel anlamda bağlayıcılığı bulunmayan belgelerle gerçekleşmiştir. Yukarıda yer verilen bulgular değerlendirildiğinde ve günümüz çevre sorunları göz önüne alındığında uluslararası alanda yapılan çalışmaların yeterli olmadığı anlaşılmaktadır.

Türkiye'nin bu konudaki çabaları incelendiğinde küresel mücadelenin gerisinde kaldığı ancak umut vadeden gelişmelerin yaşanacağı öngörülebilir. Gerek mevcut kurumsal yapı gerekse mevzuat çevresel problemlerle mücadele konusunda desteklendiği takdirde hedeflenen performansı yakalayacağı düşünülmektedir. Türkiye'nin gerçekleştirdiği çalışmaların genişletilerek ve dönüştürülerek güncellenmesi, çevre ve çevre hakkı alanının sağlıklı bir şekilde varlığını sürdürmesine olanak sağlayacaktır. Mevzuat incelendiğinde bu yöndeki çalı̧̧maların son yıllarda büyük bir artış göstermesine rağmen, toplumsal bilincin yüksek olmaması ve çevresel sorunlarının devam etmesi etkinlik konusunda büyük bir engel olarak yer almaktadır. Bu bağlamda, çevresel çalışmaların etkili bir şekilde uygulanmasının ve iç hukuka aktarılmasının, ülke anayasaları ve mevzuatlarının ancak, etkin ve verimli bir şekilde, bütüncül bir bakış açısıyla düzenlemesiyle sağlanabileceği düşünülmektedir. 
Tablo 7

Çevre Hakkına Yönelik Öneriler ve Gerekçeleri

\begin{tabular}{|c|c|c|}
\hline & ÖNERİ & GEREKÇE \\
\hline \multirow{4}{*}{$\begin{array}{l}\text { HUKUKSAL } \\
\text { BAĞLAMDA }\end{array}$} & $\begin{array}{l}\text { Anayasada çevre hakkına doğrudan etkide } \\
\text { bulunan maddelerin arttırılması. }\end{array}$ & \multirow{2}{*}{$\begin{array}{l}\text { Mevcut yasaların yeterli çevre korumasını } \\
\text { sağlayamaması. }\end{array}$} \\
\hline & $\begin{array}{c}\text { Bir önceki öneriye alternatif olarak Fransız Çevre } \\
\text { Şartı minvalinde bir metin hazırlanması. }\end{array}$ & \\
\hline & $\begin{array}{l}\text { Mevcut cezaların çeşitlendirilerek ve } \\
\text { genişletilerek etkinliğin sağlanması. }\end{array}$ & Bireysel ve toplumsal bilincin düşük olması. \\
\hline & Uluslararası belgelerin iç hukuku aktarılması. & $\begin{array}{l}\text { Uluslararası çalıșmalardan yeterince } \\
\text { faydalanamamak. }\end{array}$ \\
\hline \multirow{3}{*}{$\begin{array}{l}\text { SİYASİ VE } \\
\text { TOPLUMSAL } \\
\text { BAĞLAMDA }\end{array}$} & $\begin{array}{l}\text { İktidar ve muhalefet partilerinin çalışmalarında } \\
\text { çevresel konulara daha çok yer vermesi. }\end{array}$ & \multirow{2}{*}{$\begin{array}{l}\text { Halkın çevresel faaliyetlerde kapsamlı bir } \\
\text { şekilde yer almaması ve politika } \\
\text { uygulayıcıların çevre bilincinin yüksek } \\
\text { olmaması. }\end{array}$} \\
\hline & $\begin{array}{c}\text { Çevre koruma ve çevre hakkında eğitimler } \\
\text { verilmesi. }\end{array}$ & \\
\hline & $\begin{array}{c}\text { Çevre konusunda faaliyet gösteren STK'ların } \\
\text { desteklenmesi. }\end{array}$ & $\begin{array}{l}\text { Yeterli maddi ve manevi kaynağa } \\
\text { ulaşmaktaki güçlük. }\end{array}$ \\
\hline \multirow{3}{*}{$\begin{array}{l}\text { EKONOMIKK } \\
\text { BAĞLAMDA }\end{array}$} & $\begin{array}{l}\text { Kalkınma planlarında yer verilen çevrenin } \\
\text { uygulama kısmında da aynı özenle ele alınması } \\
\text { için yasal düzenlemeler oluşturulması. }\end{array}$ & $\begin{array}{c}\text { Planlara eklenen çevre maddelerinin } \\
\text { uygulama kısmına gelince göz ardı edilmesi } \\
\text { ve uygulama kısmında kendine yer } \\
\text { bulamaması. }\end{array}$ \\
\hline & $\begin{array}{l}\text { Çevresel harcamaların GSYİH içindeki oranının } \\
\text { arttırılması ve özel sektörün teşvik edilmesi. }\end{array}$ & $\begin{array}{l}\text { Çevresel harcamaların yeterli miktarda } \\
\text { olmaması ve AB üyesi ülkelerle } \\
\text { karşılaştırıldığın ortalamanın altında kalması. }\end{array}$ \\
\hline & $\begin{array}{c}\text { Ekonomik hedeflerin gerçekleştirilmesinde çevre } \\
\text { merkezli bir yaklaşım sergilenmesi. }\end{array}$ & $\begin{array}{l}\text { Ekonomik hedefler için çevre } \\
\text { sürdürülebilirliğinin göz ardı edilmesi. }\end{array}$ \\
\hline
\end{tabular}

Yapılan araştırma göstermektedir ki Türkiye'nin çevre hakkı konusunda yeniden ele alması gereken konular bulunmaktadır. Bu bağlamda Tablo 7'de yer alan önerilerin gerçekleştirilmesi gerekmektedir. Öncelikle hukuki sistemde, özellikle anayasada çevre hakkına doğrudan etki eden maddelerin nitelik ve nicelik bakımından arttırılması gerekmektedir. Türkiye'nin anayasal düzeyde uygulaması bulunmaktadır ve bu çevrenin korunması adına önemli bir adımdır fakat bunun doğrudan tek bir maddeyle sınırlandırılması uygulama açısından yeterli değildir. Şu anda mevcut maddenin içeriğinin geliştirilmesi ve buna ek maddeler eklenmesiyle daha güçlü bir tutum sergilenebilir. Hatta Fransız Çevre Şartı gibi bir belge ile bu durum gerçekleştirilirse daha değerli olacaktır. Bunun yanında çevreyi zarara uğratanlara yönelik verilen cezalar, caydırıcılık özelliğinin arttırılması için birkaç katına çıkarılabilir. Bunun yanında gerek bireysel gerek kamusal farkındalı̆̆ın yükseltilmesi için korumaya yönelik (kamusal alan temizliği, sosyal çevre koruma faaliyetlerinde bulunmak) kamu hizmeti cezaları yaygınlaştırılabilir. Hukuksal anlamda değinilmesi gereken bir diğer nokta ise uluslararası belgelerin iç hukuka aktarılmasıdır. Tablo 4 'te yer verilen örneklere bakılacak olursa bu konuda çalı̧̧malar yapılmış fakat bunlar hem yürürlüğe alma tarihi hem de aynı yönetmeliğin birden fazla anlaşmaya ya da sözleşme için kullanılması sebebiyle yeterli değildir. Bu konudaki yönetmelik ve genelge gibi metinlerin güncellenmesi, genişletilmesi ve eksik olanların en kısa sürede düzenlenmesi küresel çevre hakkı çalışmalarına entegre olmak açısından gerekmektedir. 
Siyasi ve toplumsal bağlamda iktidar ve muhalefet partilerinin çalışmalarına çevresel konuları dahil etmesi ve ekonomik, idari ve hukuki alanlarla ilişkilendirilerek bunun gerçekleştirilmesi çevre hakkına büyük ölçüde destek sağlayacaktır. Koyulan kuralların ve imzalanan belgelerin uygulamasını gerçekleştirecek olan idari sistem olduğu için hem kurum yapılarının bu konuda düzenlenmesi hem de uygulayıcıların bilinçlendirilmesi gerekmektedir. Toplumsal açıdan değerlendirildiğinde çevre hakkı, dayanışma temelli bir olgu olması sebebiyle sosyal sistemde önemli bir yere sahiptir. Sosyal yapı içinde yer alan bütün paydaşların bilinçlenmesine ve eğitilmesine yönelik çalışmaların yapılması çevre alanındaki çalışmaların niteliğini de arttıracaktır. Bu alanda faaliyet gösteren dernek vakıf ve sivil toplum kuruluşlarının devlet ve toplumun diğer üyeleri tarafından desteklenmesi gerekmektedir.

Son olarak ekonomik bağlamda hedeflenen ekonomik amaçların çevre merkez alınarak gerçekleştirilmesi sürdürülebilirlik açısından etkili olacaktır. Kalkınma planları incelendiğinde çevrenin yer aldığı görülmektedir fakat uygulama aşamasına gelindiğinde gerçekleştirilme oranı olması gerekenin altında kalmaktadır. Bunun önüne geçmek için daha net kanunların uygulamaya konması önem taşımaktadır. Bir başka konu ise çevresel problemler ve çevre hakkına yönelik ayrılan bütçenin arttırılması ve özel sektörün bu konuda teşvik edilmesi için çalışmaların yapılmasının gerekliliğidir. Yakın gelecekte çevreye yönelik çalışmaların seyri konusunda önemli gelişmelerin yaşanması muhtemeldir. Çünkü küresel çapta gerçekleşen salgın hastalıklarla birlikte sağlıklı bir çevrenin önemi dünya genelinde büyük ölçüde anlaşılmıştır. Kazanılan bu bilincin devam ettirilerek teknolojik gelişmelerle desteklemesi, mevcut politikaların güçlendirilmesi ve yeni politikaların sunulmasıyla çevre konusunda olumlu gelişmeler yaşanacağı öngörülebilir.

\section{Kaynakça}

2017 Yılında Mavi Yüzgeçli Orkinos Avcılığı Yapacak Gemilerin Belirlenmesi ve Bu Gemilere Yapılacak Kota Tahsisine İlişkin Tebliğ (2017, 17 Nisan). Resmî Gazete (Sayı: 30041). Erişim adresi: https://www.resmigazete.gov.tr/eskiler/2017/04/20170417-4.htm

Abdulhakimoğulları, E., Sezer, Ö. ve Akpınar, M. (2011). Küresel ulusal ve yerel düzeyde bir insan hakkı olarak çevre hakkının gelişimi. Süleyman Demirel Üniversitesi Sosyal Bilimler Enstitüsü Dergisi, 2(14), 61-88. Erişim adresi: https://dergipark.org.tr/tr/download/article-file/215794

African Union. (2020, 11 Mayis). Organization of African Unity /African Union Treaties, Conventions, Protocols and Charters. Erişim adresi: https://au.int/en/treaties/african-charter-human-and-peoplesrights.

Ağca, B. (2002). Dünya Sürdürülebilir Kalkınma Zirvesi (Johannesburg, 26 Ağustos- 4 Eylül 2002). Uluslararası Ekonomik Sorunlar Dergisi, Dışişleri Bakanlı̆̆ı Yayınları. Erişim adresi: https://www.mfa.gov.tr/dunya-surdurulebilir-kalkinma-zirvesi_johannesburg_-26-agustos---4-eylul2002_.tr.mfa

Alston, P. (1982). A third generation of solidarity rights: Progressive development or obfuscation of international human rights law? Netherlands International Law Review, 29(3), 307-322. Erişim adresi: https://www.cambridge.org/core/journals/netherlands-international-law-review/article/abs/thirdgeneration-of-solidarity-rights-progressive-development-or-obfuscation-of-international-humanrights-law/14642D2A748D146213B9401404ADA5AC

Antarktika'da Çevre Koruma Protokolünün Uygulanmasına Dair Yönetmelik. (2020, 13 Haziran). Resmî Gazete (Sayı: 31154). Erişim adresi: https://www.resmigazete.gov.tr/eskiler/2020/06/20200613-1.htm 
Atar, Y. (2007). Türk Anayasa Hukuku. Konya: Mimoza.

Aydoğdu, Y. (2017). Türk hukukunda siyasi haklar ve siyasi hakların kullanılmasının engellenmesi suçu. Türkiye Barolar Birliği Dergisi, 29(128), 85-92. Erişim adresi: http://tbbdergisi.barobirlik.org.tr/m2017$128-1623$

Aykul, Ö. (2015). Hukuk Sisteminde Temel İnsan Hakları ve Gelinen Son Aşama; Dördüncü Kuşak İnsan Hakları ve Bunları Talep Hakkı. Erişim adresi: http://www.aykultopcu.com/habervemakele-184-hukuksisteminde-temel-insan-haklari-ve-gelinen-son-asama-dorduncu-kusak-haklar-ve-bunlari-talep-hakki

Başlar, K. (2001). İnsan hakları ve kamu hürriyetleri. Ankara: SFN Televizyon Tanıtım Tasarım Yayıncılık.

Bilir, F. ve Hamdemir, B. (2011). Çevre hakkı ve uygulaması. S. Sarı ve diğerleri (Ed.), International Conference on Eurasian Economies, (s. 143-149) içinde. Bişkek: Manas University Press. Erişim adresi: http://www.avekon.org/papers/354.pdf

Black Sea Comission. (2020, 1 Haziran). The Convention on the Protection of the Black Sea Against Pollution.

Erişim adresi: http://www.blacksea-
commission.org/Official\%20Documents/The\%20Convention/Overview/

Bowen, G. A. (2009). Document analysis as a qualitative research method. Qualitative Research Journal, 9(2), 27-40. Erişim adresi: https://www.researchgate.net/publication/240807798_Document_Analysis_as_a_Qualitative_Researc h_Method

Boyar, O. ve S. Kama Işık (2019). Dördüncü kuşak haklar ve bilişim teknolojilerinin doğuşunda mahremiyet kavramına karşılaştırmalı bir bakış. Marmara Üniversitesi Hukuk Fakültesi Hukuk Araştırmaları Dergisi, 25(2), 602-623. Erişim adresi: http://static.dergipark.org.tr/articledownload/61c0/6132/82ca/5e21941546092.pdf?.

Boyd, D. R. (2012). The constitutional right to a healty hnvironment. Environment Science and Policy for Sustainable Development, $54(4), \quad 3-15 . \quad$ Erişim adresi: https://www.tandfonline.com/doi/full/10.1080/00139157.2012.691392?needAccess=true

Bozkurt, E. (2019). Çevre hakkı kapsamında İstanbul Berlin karşılaştırması (Yüksek Lisans Tezi). Marmara Üniversitesi, Sosyal Bilimler Enstitüsü, İstanbul. Erişim adresi: https://katalog.marmara.edu.tr/veriler/yordambt/cokluortam/3E30EA23-C17D-3741-86364E1A000683F8/Ecem BOZKURT.pdf

Carter, N. (2007). Politics of the environment: Ideas, activism, policy. New York: Cambridge University Press.

Ceylan, H. (2019). Çevre hakkı çerçevesinde İran'ın Unie Gölü’ndeki uygulamaları (Yüksek lisans tezi). Hacettepe Üniversitesi, Sosyal Bilimler Enstitüsü, Ankara. Erişim adresi: https://www.academia.edu/42762675/\%C3\%87EVRE_HAKKI_KAPSAMINDA_\%C4\%BOSTANBUL_ BERL\%C4\%B0N_KAR\%C5\%9EILA\%C5\%9ETIRMASI

Chauhan, B. S. (2008). Environmental studies. New Delhi: University Science Press. Erişim adresi: https://books.google.com.tr/books?id=Pw6WiYiHPhIC\&pg=PT3\&lpg=PT3\&dq=environmental+stud ies+chauhan\&source $=$ bl\&ots $=$ ZjvsNPdr- $-\&$ sig $=$ ACfU3U2SozbN 91ipDtVXQ7JPkG3mO0kGg\&hl=tr\&sa=X\&ved=2ahUKEwiU1drwLjpAhVSZMAKHdf2AyIQ6AEwDnoECBMQAQ\#v=onepage\&q=environmental\%20studies\%20ch auhan\&f=false 
Conseil Constitutionnel. (2021, 15 Mayı). Charte de l'environnement de 2004. Erişim adresi: https://www.conseil-constitutionnel.fr/le-bloc-de-constitutionnalite/charte-de-l-environnement-de2004.

Cornescu, A. V. (2009). The generations of human’s rights. D. Sehnálek ve diğerleri (Ed.), Dny Práva Days of Law 1. Edition (s. 1-11) içinde. Brno: Masaryk University. Erişim adresi: https://www.law.muni.cz/sborniky/dny_prava_2009/files/prispevky/tvorba_prava/Cornescu_Adrian _Vasile.pdf

Cullet, P. (1995). Definition of an environmental right in a human rights context. Netherlands Quarterly of Human Rights, 13(1), 25-40. Erişim adresi: https://journals.sagepub.com/doi/abs/10.1177/016934419501300103

Çevre Kanunu. (1983, 11 Ağustos). Resmî Gazete (Sayı: 18132). Erişim adresi: https://www.mevzuat.gov.tr/mevzuat?MevzuatNo=2872\&MevzuatTur=1\&MevzuatTertip=5

Çolakoğlu, E. (2010). Haklar söyleminde çevre eğitiminin yeri ve Türkiye'de çevre eğitiminin anayasal dayanakları. Türkiye Barolar Birliği Dergisi, 88, 151-171. Erişim adresi: http://tbbdergisi.barobirlik.org.tr/m2010-88-594

Dadak, K. (2015). Yeni kuşak hak olarak çevre hakkı. Uyuşmazlık Mahkemesi Dergisi, 5, 309-326. Erişim adresi: http://static.dergipark.org.tr/article-download/imported/5000145786/5000133114.pdf?

Donnelly, J. (1995). Teoride ve uygulamada evrensel insan hakları. (Çev. M. Erdoğan ve L. Korkut). Ankara: Yetkin Yayınları.

Drexhage, J. ve D. Murphy (2010). Sustainable development: From Brundlant to Rio 2012. New York: United Nations Headquarters. Erişim adresi: http://www.surdurulebilirkalkinma.gov.tr/wpcontent/uploads/2016/06/Background_on_Sustainable_Development.pdf

Eckersley, R. (2003). Environmentalism and political theory: Toward an ecocentric approach. London: UCL Press.

Elmalıca, H. (2016). Bilişim çağının ortaya çıkardığı temel bir insan hakkı olarak unutulma hakkı. Ankara Üniversitesi Hukuk Fakültesi Dergisi, 65(4), 1603-1636. Erişim adresi: https://dergipark.org.tr/tr/download/article-file/621578

Erdoğan, M. (2016). Çevresel bilgiye erişim hakkı açısından Aarhus Sözleşmesi ve Türkiye üzerine değerlendirme. Uluslararası Sosyal Araştırmalar Dergisi, 9(43), 1812-1817. Erişim adresi: https://avesis.comu.edu.tr/yayin/774f8187-47bf-48ef-8a99-b0f2e2f2bd1d/cevresel-bilgiye-erisimhakki-acisindan-aarhus-sozlesmesi-ve-turkiye-uzerine-degerlendirme

Eroğlu, Ş. (2018). Dijital yaşamda mahremiyet (gizlilik) kavramı ve kişisel veriler: Hacettepe Üniversitesi Bilgi ve Belge Yönetimi Bölümü öğrencilerinin mahremiyet ve kişisel veri algılarının analizi. Hacettepe Üniversitesi Edebiyat Fakültesi Dergisi, 35(2), 130-153. Erişim adresi: https://www.researchgate.net/publication/328022624_Dijital_Yasamda_Mahremiyet_Gizlilik_Kavram i_ve_Kisisel_Veriler_Hacettepe_Universitesi_Bilgi_ve_Belge_Yonetimi_Bolumu_Ogrencilerin_Mahre miyet_ve_Kisisel_Veri_Algilarinin_Analizi

Eurostat. (2021a, 15 Şubat). Environmental Protection Expenditure Accounts. Erişim adresi: https://ec.europa.eu/eurostat/statisticsexplained/index.php/Environmental_protection_expenditure_accounts

Eurostat. (2021b, 13 Şubat). National Expenditure on Environmental Protection. Erişim adresi: https://ec.europa.eu/eurostat/databrowser/view/ten00135/default/table?lang=en 
Eurostat. (2021, 4 Ocak). General Government Expenditure by Function. Erişim adresi: https://appsso.eurostat.ec.europa.eu/

Feinberg, J. (1970). The nature and value of rights, Journal of Value Inquiry, 4, 243-257. Erişim adresi: https://link.springer.com/article/10.1007/BF00137935

Friends of the Earth International. (2021, 9 Şubat). Environmental Rights are Human Rights. Erişim adresi: https://www.foei.org/what-we-do/environmental-rights-human-

rights\#: :text=Environmental\%20rights\%20mean\%20access\%20to,\%2C\%20food\%2C\%20water\%20an d\%20air.\&text=Many\%20of\%20these\%20rights\%2C\%20particularly,in\%20various\%20conventions\%2 0and\%20agreements.

Glass, S. M. (2002). Sustainability and local government. Local Environment, 7(1), 97-102. https://doi.org/10.1080/13549830220115448

Gözler, K. (2012). Hukukun temel kavramları. Bursa: Ekin Basım Yayın Dağıtım.

Gülmez, M. (2001). İnsan hakları ve demokrasi eğitimi. Ankara: TODAİE Yayını.

Gündüzöz, İ. (2015). Yeni kuşak insan hakları çerçevesinde Türkiye'de mülki idare amirliğine analitik bir yaklaşım. İnsan Hakları Yılliğı, 33, 19 - 33. Erişim adresi: https://docplayer.biz.tr/35271943-Yeni-kusakinsan-haklari-cercevesinde-turkiye-de-mulki-idare-amirligine-analitik-bir-yaklasim.html

Güneş, A. (2012). Uluslararası çevre hukuku üzerine bir inceleme. Journal of Istanbul University Law Faculty, 70(1), 83-114. Erişim adresi: https://dergipark.org.tr/tr/download/article-file/97703

Güneş, A. ve L. Münster (2010). Aarhus Sözleşmesi üzerine bir inceleme. Gazi Üniversitesi Hukuk Fakültesi Dergisi, 14(1), 299-333. Erişim adresi: http://webftp.gazi.edu.tr/hukuk/dergi/14_1_11.pdf

Güneş, A. ve L. Münster (2011). Yeni anayasa tartışmaları bağlamında çevre. Ankara Hacı Bayram Veli Üniversitesi Hukuk Fakültesi Dergisi, 15(3), 259-284. Erişim adresi: http://webftp.gazi.edu.tr/hukuk/dergi/15_3_10.pdf

Güneş, Y. ve A. A. Coşkun (2004). Çevre hukuku. İstanbul: Kazancı Hukuk Yayınları.

Güveyi, Ü. (2018). 1982 Anayasası kapsamında çevre hakkının karşılaştırmalı kısa bir tahlili. Marmara Üniversitesi Hukuk Fakültesi Hukuk Araștırmaları Dergisi, 24(2), 633-659. Erişim adresi: http://static.dergipark.org.tr/article-download/be03/588c/e94b/5c23494d86d08.pdf?

Hamamcı, C. (1983-1984). Çevre hakkı üzerine düşünceler. İnsan Hakları Yılliğı, 5-6, 171-180. Erişim adresi: http://docplayer.biz.tr/30092566-Cevre-hakki-uzerine-dusunceler-can-hamamci.html

Hohfeld, W. (1919). Fundamental legal conceptions. (Ed. W. Cook), New Haven: Yale University Press.

İstediğimiz Gelecek. (Haziran 2012). Birleşmiş Milletler Sürdürülebilir Kalkınma Konferansı (Rio+20) Rio de Janeiro, Brezilya, 20-22 Haziran 2012, Konferans Çıktısı Erişim adresi: http://www.surdurulebilirkalkinma.gov.tr/wp-content/uploads/2016/06/Future_We_Want.pdf

Kaboğlu, İ. Ö. (1992). Çevre hakkı. İstanbul: İletişim Yayınları.

Kaboğlu, İ. Ö. (1998). İnsan haklarının hukuksal yapısı (Özgürlükler hukuku). İstanbul: AFA Yayınları.

Kanlı, İ. B. ve B. Kaplan (2019). Yerel ölçekte çevre güvenliğine ilişkin bir model önerisi. Kırklareli Üniversitesi İktisadi ve İdari Bilimler Fakültesi Dergisi, 8(2), 97-115. Erişim adresi: https://dergipark.org.tr/tr/pub/klujfeas/issue/48895/440546

Kapani, M. (1981). Kamu hürriyetleri. Ankara: Ankara Üniversitesi Hukuk Fakültesi Yayını. 
Kara, U. (2012). Üçüncü kuşak haklar: Dayanışma hakları. (Ed. Tolga Akkaya). Temel İnsan Hakları Bilgisi I. Anadolu Üniversitesi Yayını No: 2538, Açıköğretim Fakültesi Yayını No: 1509, 90-105. Erişim adresi: http://www.nevoku.com/temel-insan-haklari-bilgisi---i---e-kitap--temel-insan-haklari-bilgisii/viewdeck/0be1bde6-692e-4502-b8e1-a0c335aa7802

Kaya, Y. (2011). Çok taraflı çevre anlaşmalarına uyum sorunu ve Türkiye üzerine bir değerlendirme. Süleyman Demirel Üniversitesi İktisadi ve İdari Bilimler Fakültesi Dergisi, 16(2), 439-462. Erişim adresi: https://www.acarindex.com/dosyalar/makale/acarindex-1423912722.pdf

Kaypak, Ş. (2009). Avrupa Birliği sürecinde yerel haklar ve kente yansıması. I. Uluslararası Avrupa Birliği, Demokrasi, Vatandaşlık ve Vatandaşlık Eğitimi Sempozyumu. 28-30 Mayıs 2009, Uşak. 1-19. Erişim adresi:

https://www.academia.edu/32443038/Avrupa_Birli\%C4\%9Fi_S\%C3\%BCrecinde_Yerel_Haklar_ve_Ke nte_Yans\%C4\%B1mas\%C4\%B1?auto=download

Kaypak, Ş. (2017). Çevre hakkı ve kentsel alanlarda uygulanması. (Ed. Z. Altaev, Z. Suleımenova, Ö. O. Fettahlıglu) Al Farabi 1. Uluslararası Sosyal Bilimler Kongresi Congress Book, 1037-1059, Gaziantep, İKSAD. Erişim adresi: https://www.researchgate.net/publication/323551194_CEVRE_HAKKI_VE_KENTSEL_ALANLARD A_UYGULANMASI

Keleş, R. Y. (1994). Kent ve çevre haklarının korunması üzerine gözlemler. Ankara Üniversitesi Siyasal Bilgiler Fakültesi Dergisi, 49(3), 275-281. https://doi.org/10.1501/SBFder_0000001726

Keleş, R. (2013). 100 soruda çevre, çevre sorunları ve çevre politikası. İzmir: Yakın Kitabevi.

Keleş, R. ve Ertan, B. (2002). Çevre hukukuna giriş. Ankara: İmge Kitabevi.

Kıral, B. (2020). Nitel bir veri analizi yöntemi olarak doküman analizi. Sosyal Bilimler Enstitüsü Dergisi, 15, 170-189. Erişim adresi: https://dergipark.org.tr/tr/download/article-file/1156348

Kıyı Kanunu. (1990, 17 Nisan). Resmî Gazete (Sayı: 20495). Erişim adresi: https://www.mevzuat.gov.tr/MevzuatMetin/1.5.3621.pdf

Legifrance. (2020, 16 Mayıs). Traités internationaux. Erişim adresi: https://www.legifrance.gouv.fr/Droitinternational/Traites

Louden, R. (1983). Rights infatuation and the impoverishment of moral theory. Journal of Value Inquiry, 17, 87-102. https://doi.org/10.1007/BF00158554

Milli Parklar Kanunu. (1983, 9 Ağustos). Resmî Gazete (Sayı: 18132). Erişim adresi: https://www.mevzuat.gov.tr/MevzuatMetin/1.5.2873.pdf

Mumcu, A. (2007). İnsan hakları ve kamu özgürlükleri kavramı. (Ed. A.T. Yürük, K. Selvi). İnsan Hakları ve Kamu Özgürlükleri. Anadolu Üniversitesi Yayını No: 1590, Açı̈öğretim Fakültesi Yayını No: 842.

Mutlu, L. (2011). Anayasal bir hak olarak çevre hakkı ve çevresel etki değerlendirmesi (Yüksek Lisans Tezi). Kafkas Üniversitesi, Sosyal Bilimler Enstitüsü, Kars. Erişim adresi: https://tez.yok.gov.tr/UlusalTezMerkezi/tezSorguSonucYeni.jsp

OECD. (2005, 5 Temmuz). Environment. Erişim adresi: https://stats.oecd.org/glossary/detail.asp?ID=813

OECD. (2008). OECD Çevresel Performans İncelemeleri: Türkiye. Erişim adresi: https://www.oecd.org/env/country-reviews/42198785.pdf

O'Leary, Z. (2017). The essential guide to doing your research project. London: Sage. 
Olgun, H. ve V. Işık (2017). Bir “İnsan Hakkı” olarak “Çevre Hakkı” ve Türk Hukukundaki yeri. Uluslararası Politik Araştırmalar Dergisi, 3(1), 33-52. Erişim adresi: https://dergipark.org.tr/tr/download/articlefile/598894

Organization of American States. (2020, 11 Haziran). Additional Protocol to the American Convention on Human Rights in the Area of Economic, Social and Cultural Rights "Protocol of San Salvador". Erişim adresi: http://oas.org/juridico/English/treaties/a-52.html

Özdek, E. Y. (1993) İnsan hakkı olarak çevre hakkı. Ankara: TODAİE Yayını.

Özmehmet, D. E. (2008). Dünyada ve Türkiye sürdürülebilir kalkınma yaklaşımları. Journal of Yaşar University, 3(12), 1-23. Erişim adresi: https://docplayer.biz.tr/4366960-Dunyada-ve-turkiyesurdurulebilir-kalkinma-yaklasimlari-dr-ecehan-ozmehmet-yasar-universitesi-ecehan-ozmehmetyasar-edu-tr.html

Öztürk, Ö. (2017). Çevrecilik söylemleri ve Türkiye'deki çevre hareketlerinin seyri. Journal of History Culture and Art Research, 6(2), 441-456. Erişim adresi: http://193.140.9.50/index.php/ilk/article/view/804/621

Prüss-Ustün, A., Wolf, J., Corvalán, C., Bos, R. ve Neira, M. (2016). Preventing disease through healthy environments. A global assessment of the burden of disease from environmental risks. Geneva: World Health Organization Press. Erişim adresi: https://apps.who.int/iris/bitstream/handle/10665/204585/9789241565196_eng.pdf?sequence=1\&isAll owed $=\mathrm{y}$

Refworld. (2020, 12 Haziran). World Charter for Nature. Erişim adresi: https://www.refworld.org/docid/3b00f22a10.html

Semiz, Y. (2016). Çevre hakkı kavramı ve Avrupa İnsan Hakları Mahkemesinin çevre hakkına yaklaşımı (Yüksek Lisans Tezi). Galatasaray Üniversitesi, Sosyal Bilimler Enstitüsü, İstanbul. Erişim adresi: https://tez.yok.gov.tr/UlusalTezMerkezi/tezDetay.jsp?id=d9A42DeE6VQqAnUb_9UpCQ\&no=L05N DnpBiNILRyCvliwqTA

Su Ürünleri Kanunu. (1971, 22 Mart). Resmî Gazete (Sayı: 13799). Erişim adresi: https://www.mevzuat.gov.tr/MevzuatMetin/1.5.1380.pdf

Şen, E. (1994). Çevre ceza hukuku. İstanbul: Kazancı Hukuk Yayınları.

Tarlock, A. D. (2009). History of environmental law. Environmental laws and their enforcement, (Ed. A. D. Tarlock, J. C. Dernbach). 1, 42-64, Oxford: EOLSS Publications.

T.C. Anayasası (1924). Erişim adresi: https://www.anayasa.gov.tr/tr/mevzuat/onceki-anayasalar/1924anayasasi/

T.C. Anayasası (1961). Erişim adresi: https://www.anayasa.gov.tr/tr/mevzuat/onceki-anayasalar/1961anayasasi/

T.C. Anayasası. (1982). Erişim adresi: https://www.mevzuat.gov.tr/MevzuatMetin/1.5.2709.pdf

T.C. Çevre ve Orman Bakanlığı. (2020, 10 Haziran). Rio Sözleşmeleri Kapsamında Türkiye’nin Ulusal Kapasitesinin Değerlendirilmesi Projesi. Erişim adresi: http://www.ncsa-turkey.cevreorman.gov.tr/riosozlesmeleri.aspx

T.C. Çevre ve Şehircilik Bakanlığı. (2020a, 1 Haziran). BM İklim Değişikliği Çerçeve Sözleşmesi. Erişim adresi: https://iklim.csb.gov.tr/birlesmis-milletler-iklim-degisikligi-cerceve-sozlesmesi-i-4362 
T.C. Çevre ve Şehircilik Bakanlığı. (2020b, 1 Haziran). Montreal Protokolü. Erişim adresi: https://iklim.csb.gov.tr/montreal-protokolu-i-4364

T.C. Çevre ve Şehircilik Bakanlığı. (2020c, 1 Haziran). Viyana Sözleşmesi. Erişim adresi: https://iklim.csb.gov.tr/viyana-sozlesmesi-i-4399

T.C. Çevre ve Şehircilik Bakanlığı. (2020d, 11 Nisan). Çevre Koruma Harcamaları. Erişim adresi: https://cevreselgostergeler.csb.gov.tr/cevre-koruma-harcamalari-i-85708

T.C. Çevre ve Şehircilik Bakanlığı, Çevresel Etki Değerlendirmesi, İzin ve Denetim Müdürlügü. (2016). Türkiye Çevre Durum Raporu, Ankara: SAR MATBAA Yayıncıllk. Erişim adresi: https://webdosya.csb.gov.tr/db/ced/editordosya/tcdr_tr_2015.pdf

T.C. Çevre ve Şehircilik Bakanlığı, Çevresel Etki Değerlendirmesi, İzin ve Denetim Müdürlügü. (2020). Çevresel Göstergeler, Ankara: Bee Content \& Communication. Erişim adresi: https://webdosya.csb.gov.tr/db/cevreselgostergeler/duyurular/cevresel-gostergeler--8230-4625020210105115222.pdf

T.C. Dışişleri Bakanlığı. (2020a, 9 Mayı). Sürdürülebilir Kalkınma. Erişim adresi: http://www.mfa.gov.tr/surdurulebilir-kalkinma.tr.mfa.

T.C. Dışişleri Bakanlığı. (2020b, 15 Mayıs). Ülkemizin Taraf Olduğu Başlıca Çevre Anlaşmaları. Erişim adresi: http://www.mfa.gov.tr/data/DISPOLITIKA/Anlasmalar.pdf.

The Declaration of the United States of America. (1776, 4 Temmuz). Erişim adresi: http://www.digitalhistory.uh.edu/active_learning/explorations/revolution/dunlap.jpg

Topçu, E. (2008). Bir insan hakkı olarak su hakkı. İnsan Hakları Yıllığı, 26, 15-40. Erişim adresi: https://docplayer.biz.tr/196228-Bir-dnsan-hakki-olarak-su-hakki.html

TÜİK. (2020, 28 Ekim). Çevre Koruma İstatistikleri. Erişim adresi: https://data.tuik.gov.tr/tr/main-categorysub-categories-sub-components2/

UNECE. (2020, 14 Mayıs). Erişim adresi: https://www.unece.org/env/pp/introduction.html.

UNEP. (2020, 25 Nisan). Erişim adresi: www.unep.org/search-environment-right

UNEP. (2021, 10 Şubat). Erişim adresi: https://www.unenvironment.org/explore-topics/environmentalrights-and-governance/what-we-do/advancing-environmental-rights/what-0

United Nations Treaty Collection. (2020, 11 Mart). Treaty American Convention on Human Rights "Pact of San José, Costa Rica. Erişim adresi: https://treaties.un.org/pages/showDetails.aspx?objid=08000002800f10e1

Uygun, O. (2000). İnsan hakları kuramı. İstanbul: Yapı Kredi Yayınları.

Uygun, O. (2013). Kamu hukuku incelemeleri. İstanbul: Oniki Levha Yayıncılık.

Vašák, K. (1977). Human rights: A thirty-year struggle: the sustained efforts to give force of law to the universal declaration of human rights. UNESCO Courier, 11, 29-32. Erişim adresi: https://unesdoc.unesco.org/ark:/48223/pf0000074816

Vie Publique. (2020, 15 Haziran). Quels sont les principes, droits et devoirs consacrés par la Charte de l'environnement de 2004? Erişim adresi: https://www.vie-publique.fr/fiches/19567-charte-delenvironnement-principes-droits-et-devoirs

Yurtcanlı, S. (2012). Fransız Çevre Şartı'na bir bakış. Journal of Faculty of Political Science, 21(47), 309-334. Erişim adresi: https://dergipark.org.tr/tr/download/article-file/5702 
Warman, C. (2016). Tolerance: The beacon of the enlightenment. Cambridge: Open Book Publishers. Erişim adresi: https://www.jstor.org/stable/j.ctt19b9jvh.6?seq=1\#metadata_info_tab_contents

Wood, Harold W. (1985). The united nations world charter for nature: The developing nations initiative to establish protections for the environment. Ecology Law Quarterly, 12, 977-996. Erişim adresi: https://www.jstor.org/stable/24112833?seq=1

World Resources Institute. (2021, 15 Şubat). Environmental Rights. Erişim adresi: https://www.wri.org/ourwork/topics/environmental-rights

\section{Extended Abstract}

\section{Purpose}

This study is mainly based on evaluating the relationship between environmental rights and the right to solidarity (Third Generation Rights) and the development process of the relationship between these two concepts. The concept's place in human rights dates back to 1972. The environmental right, which was recognized as a human right at the Human Environment Conference held by the United Nations, officially took its place among the third-generation rights in 1982, with the "International Third Pact Pre-Draft on Solidarity Rights". In the subsequent developing process, it was aimed to strengthen the right to environment by organizing various conferences, conventions, and agreements both locally and globally. The aim of this article is to examine the development of the Environmental right as a right of solidarity in international legislation and to analyse the reflections of this development on Turkey and to reveal the way and performance taken in this regard.

\section{Design and Methodology}

In this study, where qualitative research methods are used, literature review, technical reports and analysis of national and international institutions and organizations were used. The study consists of an introduction, basic concepts, environmental right in the international arena, environmental right in Turkey, evaluation, conclusion and recommendations sections. After the introduction of general information about the study and parameters such as the importance, subject, method, and purpose of the article, it was continued with the basic concepts and theoretical framework section. This chapter is divided into two subheadings, the first of which focuses on the relationship between the environmental right and the human right. This part, which details concepts such as the environment, the right to the environment and the human right, was terminated by evaluating the relationship between the right to the environment and the generations of human rights. In the second subheading, the relationship between third-generation rights and environmental rights, one of the generations of human rights, is examined. In the next title, the development of the right to environment in the international arena is examined in the context of conferences, conventions and agreements and the subject is reinforced with the example of France. This section, which examines the environmental condition of France, is concluded with the evaluation of environmental protection expenditures. In the continuation of the study, in parallel with the previous title, the development of the environmental right in Turkey and the process it has undergone is analysed. In this context, issues such as the transposition of international agreements and environmental protection expenditures are included. In the continuation of the section titled evaluation, in which the obtained findings were analysed, the study was concluded with the results and recommendations. 


\section{Findings}

The inclusion of the environment as a direct right in the international arena was recognised by the UN Declaration on the Human Environment. Environmental right, which is seen as a prerequisite for accessing fundamental rights, has taken its place among the solidarity rights with the International Third Pact Pre-Draft on Solidarity Rights. The concept, which is based on human-induced phenomena and the idea of environmentalism, has an intergenerational quality and includes future generations as it has many elements. The environmental right, which cannot fit into certain temporal and spatial patterns, has expanded its sphere of influence by integrating it into various areas such as sustainable development. It was in the 1970s that the right to the environment became more visible than previous years and began to enter the constitutions. In Turkey, it was directly included in the constitution in 1982. Apart from international conferences, there are conventions such as the San Salvador Protocol, The African Charter on Human and Peoples' Rights, the Charter of Nature and the Aarhus Convention, which are directly related to the environmental rights. These documents, that deal with the right to the environment from various angles, played an important role in the development and strengthening of the concept. France, which was selected as a model country in this study, has signed many national and international studies, but the main reason for its inclusion in this study is the Environmental Charter, which was added to the Constitution of France on March 1, 2005. The importance of the Environmental Charter is that it deals with the environmental right, which is included in one article in the Constitutions of other countries, as a separate 10-article text. The main purpose of the Charter can be explained as bringing together and protecting the principles found in different legislation and determined in accordance with the protection of the environment on a constitutional plane.

In Turkey, there are various studies, both directly and indirectly. Article 56 of the Turkey Constitution which was entered into force in 1982 is the basis of the environmental right. Practices performed are not limited to those mentioned in the article, but those considered important as a result of the scan were included in the study. If a brief evaluation is made in line with the studies discussed; although the conferences, agreements and many other documents held in the international arena have made positive contributions to the environmental issue, they have not reached the desired level. If an evaluation is made in terms of France; although there are important studies, the most striking issue has been the Environmental Charter. Although Turkey is striving for the environment, when even the world has not yet come a long way, it is thought that in the coming years, expectations will be met, and positive results of the past studies will be seen.

\section{Research Limitations}

This study is limited by the policies of the UN, Turkey and France, which are seen as important on the right to the environment after 1970, and the effects and qualities of these policies which have been ongoing.

\section{Implications}

At first, the articles that directly affect the right to environment in the legal system, especially in the constitution, should be increased in terms of quality and quantity. A stronger attitude can be achieved by improving the content of the existing article covering the right to environment and adding additional articles to it. This will be more valuable if it is realized with a document such as the French Environmental Charter. In addition, penalties for those who damage the environment can be doubled to increase deterrence. Public Service penalties for protection (cleaning of public spaces, engaging in social environmental protection activities) can also be disseminated in order to raise individual and public awareness. Another point that should be addressed in a legal sense is the transpose of international documents to domestic law. Updating, expanding, and editing conventions such as regulations and circulars regarding this issue as soon as possible is significant for integrating into the work of the global environmental right. 
In the political and social context, the inclusion of environmental issues in the work of the ruling and opposition parties and achieving this by blending them with other fields will greatly support the right to environment. In social terms, the environmental right has an important place in the social system due to the fact that it is a solidarity-based phenomenon. Conducting studies aimed at raising awareness and educating all stakeholders involved in the social structure will also increase the quality of Environmental Studies. Associations, foundations and non-governmental organizations operating in this area should be supported by the state and other members of society.

In the economic context, the targeted economic objectives are based on the environment, which will be effective in terms of sustainability. Another issue is the need to increase the budget which is allocated for environmental problems and environmental rights and to encourage the private sector in this regard. It is likely that important developments will occur in the course of environmental studies in the near future since the importance of a healthy environment has been widely understood around the world with the global epidemic diseases. By continuing this awareness gained and blending it with technological developments, strengthening existing policies and supporting it with new policies, it can be predicted that positive developments in the environment will occur.

\section{Originality/Value}

The study is considered significant since it has the potential to contribute to local, national, and international studies and the policies they would develop and to bring a new approach to the literature on environmental rights.

Araştırmacı Katkısı: İmam Bakır KANLI (\%50), İsmail Tarık KÜPELİ (\%50). 